\title{
STATE-INTEREST ANALYSIS IN FOURTEENTH AMENDMENT "PRIVACY" LAW: AN ESSAY ON THE CONSTITUTIONALIZATION OF SOCIAL ISSUES
}

\author{
Carl E. Schneider*
}

INTRODUCTION

Asked to resolve a social issue, Americans today turn readily to rights ${ }^{1}$ and to the Constitution that is understood to embody them. Many "vice" issues have long been thought particularly apt for a rights analysis. A constitutional resolution of vice issues is therefore inevitably a possibility, and its wisdom is inevitably a question. In this essay, I want to address that question by investigating an area of the law that has been recently constitutionalizedfamily law. Family law is an example worth studying because rights thinking has won a considerable prominence in it: The Constitution has been used to transform some major aspects of family law and to cast a shadow on many others. In addition, rights thinking of a more general kind-influenced by constitutional ideas, but not exclusively constitutional-has come to shape much thought, legal and lay, about both family law and family life. Family law has not only had illuminating experience with rights thinking and constitutionalization; its experience has been with the most relevant form of each. For if vice issues are constitutionalized, it probably will be through the doctrinal framework of fourteenth amendment "privacy" rights developed and applied in family law cases. ${ }^{2}$

\footnotetext{
Copyright $\odot 1988$ by Law and Contemporary Problems

- Professor of Law, University of Michigan. I am grateful to Philip Cook, Edward Cooper, Walter E. Dellinger, Alfred A. DeSimone, Marie Deveney, Jerold H. Israel, Robert F. Nagel, Frederick Schauer, Dorothy Schneider, Joan W. Schneider, Jerome Skolnick, Lee Teitelbaum, and Maris Vinovskis for their comments on an earlier draft of this essay.

1. See, e.g., Stewart, Federalism and Rights, 19 Geo. L. Rev. 917 (1985); Westen, The Rueful Rhetoric of "Rights, " 33 UCLA L. REv. 977 (1986)

2. Indeed, to some extent I will be directly discussing "vice" issues or issues (like abortion) which are associated with true "vice issues." I have in mind, of course, family law legislation that might be thought to have primarily a "moral" justification-that is, the kind of legislation which has been controverted since Mill and Stephen and Hart and Devlin. Such legislation includes some kinds of statutes regulating entrance into marriage (polygamy and incest statutes, for example), statutes prohibiting non-marital sexual relations (fornication, cohabitation, adultery, and prostitution statutes, for example), some kinds of statutes governing reproductive activities (abortion,
} 
I do not, however, intend (or perhaps need) to take on the entire sweep of problems privacy rights present; rather, I wish to examine the unexamined. As the lawyers among my readers will know, constitutional doctrine divides decisions about statutes challenged in terms of fundamental fourteenth amendment privacy rights into two parts: First, does the statute infringe some individual right? Second, is some state interest nevertheless powerful enough to justify the statute? Most writing about privacy rights is devoted to the pleasures of identifying, describing, and defending individual rights. The state-interest side of the constitutional formula is generally scanted. I wish to redress that balance by investigating the role of the state's interest in legislation that impinges on privacy rights. In doing so, I will hope to learn more about the desirability of using the fourteenth amendment to approach family law problems generally and "vice" issues specifically.

This symposium on vice will attract laymen as well as lawyers. I hope that this essay will speak to both audiences. However, it has two sections. In the first-part II-I analyze in conventional legal terms some doctrinal aspects of the Court's treatment of state interests. Specifically, I examine the Court's travails in developing tests to use in state-interest analysis, in defining the terms of those tests, and in applying them. In the essay's second sectionparts III through V-I address rather more speculatively some broader aspects of a constitutionalized family law. Particularly, I ask whether states may define their interests in broader terms than the Court has so far contemplated and whether the Court's constricted state-interest analysis has had deleterious political and social consequences. Both sections of the essay, I believe, engage the question of how far family law and vice issues should be constitutionalized, but the first section-because it takes doctrine seriouslymay be of livelier interest to lawyers than to social scientists. Thus, I counsel the lay reader to consider turning directly to the second section, which begins at part III.

I undertake this topic with some hesitation. First, it treats only one side of a two-sided problem: To analyze the state interests in a statute or in the abstract without assessing the personal rights they confront and without weighing the two claims against each other is to leave important issues unexplored and one's ultimate conclusions about rights analysis unformed. ${ }^{3}$ Second, the topic is complex, and even in the generous space I have been permitted, I can only sketch a rough chart of my argument, one devoid of the cross-currents, eddies, depths, and shoals which are already too blithely and too hazardously ignored in explorations of constitutional rights. ${ }^{4}$

contraception, and adolescent sexual relations), and statutes prohibiting what are understood to be deviant sexual relations (homosexuality).

3. My own ultimate conclusions about these statutes are indeed incomplete. I have, however, begun to examine the rights side of the equation in Schneider, Rights Discourse and Neonatal Euthanasia, 76 Calif. L. Rev. 151 (1988).

4. Not only will I be unable to develop fully all the arguments I make, but I will ignore a number of aspects of state-interest analyses. For example, I will not discuss the extent to which a legislature must actually have relied on or the state's lawyer actually have advanced a justification for 
Perhaps at this point I owe laymen a word of explanation and lawyers a word of reminder about the doctrinal framework of the fourteenth amendment doctrine of "substantive due process," for it is that doctrine in which the right of privacy is embedded. The due process clause of the fourteenth amendment provides that no state shall "deprive any person of life, liberty, or property, without due process of law . ..." This clause on its face seems to create only procedural limits on the power of government, but it has in two periods in history been taken to impose substantive limits as well. The first such period was the late nineteenth and early twentieth centuries, when the Court interpreted the clause as guaranteeing various laissez-faire economic freedoms, particularly the freedom of contract. ${ }^{5}$ The second such period has been the last twenty years, when the Court has interpreted the clause as guaranteeing a right to "privacy." Constitutional privacy has an artificial meaning most easily understood by looking at the specific rights it has been held to encompass. An authoritative formulation states: "the right has some extension to activities relating to marriage, ... procreation, . . . contraception, ... family relationships, . . . and child rearing and education." 6 The right to privacy is a "fundamental" right, and statutes that infringe such rights bear a heavy burden of justification: They must be "necessary" to serve a "compelling state interest." In contrast, the ordinary run of statutes is presumed to be constitutional and thus needs only be "rationally related" to a "permissible state purpose."7 Generally, the decision which test to apply has been outcome-determinative. That is, statutes to which the compelling-stateinterest test is applied are almost invariably found unconstitutional; statutes to which the rationally-related test is applied are almost invariably upheld.

\footnotetext{
a statute before a court may consider that justification. Nor, to take another example, will I attempt to canvass all the interests that ought to be "compelling." Nor, again, will I fully examine the interactions between state-interest analysis in privacy cases and in other forms of constitutional adjudication. This piece is, as its title indicates, an essay, not a treatise (or even a law review article): In it, I reflect on some central features of state-interest analysis; I do not detail and dissect every feature of it.

5. This period is commonly referred to as the Lochner era, after Lochner v. New York, 198 U.S. 45 (1904), in which the Court held that a statute limiting the working hours of bakery employees (in order to limit the harmful effects of flour dust on workers) violated the right of employees freely to contract with employers.

6. Roe v. Wade, 410 U.S. 113, 152 (1973).

7. A few fundamental-rights "privacy" cases arise under the fourteenth amendment's equal protection clause. For our purposes, equal protection analysis closely resembles substantive-dueprocess analysis. Equal protection cases test the legitimacy of legislative classifications that result in differential treatment of similarly situated people. When a legislative classification implicates a fundamental right (privacy, in our cases) or when it uses a suspect classification (such as race), it must be "strictly scrutinized" to see if it meets the same heavy burden of justification used in substantivedue-process analysis. When a legislative classification does not implicate a fundamental right, it need only meet the light burden of justification. For an illuminating discussion of the Court's use of such formulaic tests, see Nagel, The Formulaic Constitution, 84 Mich. L. Rev. 165 (1985).
} 


\section{An Analysis of the State-Interest Tests}

In this part, I will suggest that the state-interest side of the substantivedue-process ledger has generally not been well handled by courts and commentators: courts have had problems articulating and applying a test; commentators have scanted those problems. ${ }^{8}$ I will suggest that the judicial awkwardness and scholarly inattention are due to some basic dilemmas of fourteenth amendment privacy doctrine. To locate those dilemmas, I will examine three areas of difficulty. The first such area lies in the Supreme Court's failure to devise a satisfactory standard of review; the second lies in its failure to decide what its chosen standard of review means; the third lies in its failure to apply that standard sensitively and sensibly.

\section{A. The Uncertain Standard of Review}

The first area of difficulty with state-interest analysis-the Court's failure to devise a satisfactory standard of review-is signaled by the fact that the present standard is less firmly established than one might suppose. Many recent cases, of course, recite the conventional understanding I described earlier-that a statute which infringes a "fundamental" right must be "necessary" to promote a "compelling state interest." However, this test is something of a novelty in privacy law, and even now it is not regularly used.

The novelty of the modern test is notable enough to warrant a brief history of the Court's struggles to find a satisfactory standard of review in privacy cases. The origins of the privacy right lie in the 1920's, in two cases from the first period of substantive due process-Meyer $v$. Nebraska ${ }^{9}$ and Pierce $v$. Society of Sisters ${ }^{10}$-each of which involved statutes limiting parents' choices about their children's education. Meyer and Pierce used the old (and by modern standards tame)" substantive-due-process standard of review: "rights guaranteed by the Constitution may not be abridged by legislation which has no reasonable relation to some purpose within the competency of the

8. For one example of a commentator's treatment, see-the otherwise droll-Note, Fornication, Cohabitation, and the Constitution, 77 Мich. L. REv. 252 (1978), which displays the commentator's typical uninterest in the state-interest problem by managing to spend 45 pages on the fundamentalrights issue and only nine pages on the state's interests. Commentators have, however, devoted more considerable attention to state-interests aspects of "rationality" review, to, that is, the question of the kind of review appropriate to a statute that does not infringe a fundamental right or create a suspect classification. See Gunther, Foreword: In Search of Evolving Doctrine on a Changing Court: A Model for a Newer Equal Protection, 86 Harv. L. REv. 1 (1972); Linde, Due Process of Lawmaking, 55 NEBR. L. REv. 197 (1976); Bennett, "Mere" Rationality in Constitutional Law: Judicial Review and Democratic Theory, 67 Calif, L. Rev. 1049 (1979); Bice, Rationality Analysis in Constitutional Law, 65 Minn. L. REv. 1 (1980); Michelman, Politics and Values or What's Really Wrong with Rationality Review?, 13 CreIGHTON L. REv. 487 (1979).

9. 262 U.S. $390(1923)$.

10. 268 U.S. $510(1925)$.

11. It bears emphasizing that the standard of review in the Lochner era (that the law have "a reasonable relation to some purpose within the competency of the state") was, at least in principle, markedly more forgiving than the modern era's standard. 
State."12 In 1942, in Skinner v. Oklahoma ${ }^{13}$ (an equal protection case not then thought related to Meyer and Pierce but now sometimes taken to be), the Court said that, since legislation requiring the sterilization of anyone who committed three felonies implicated "one of the basic civil rights of man," "strict scrutiny" of the classification was necessary. ${ }^{14}$ However, strict scrutiny did not then, as it does now, require courts to use the modern standard of review; in Skinner it seemed only to mean something more demanding than the usual degree of deference to legislative decisions. Finally, in the last of the four early privacy cases, Prince $v$. Massachusetts, 15 the Court said, "[W]hen state action impinges upon a claimed religious freedom, it must fall unless shown to be necessary for or conducive to the child's protection against some clear and present danger . . . "16 In sum, the early privacy cases introduced neither the modern rigorous standard of review nor indeed any single standard of review.

Nor did the compelling-state-interest standard appear in the avatar of the modern privacy right, Griswold $v$. Connecticut. ${ }^{17}$ Rather, in overturning a statute prohibiting the use of contraceptives, the Griswold Court quoted NAACP $v$. Alabama 18 to the effect that a " "governmental purpose to control or prevent activities constitutionally subject to state regulation may not be achieved by means which sweep unnecessarily broadly and thereby invade the area of protected freedoms." "19 Griswold's doctrinal foundation was too ingenious and too idiosyncratic permanently to support a strong privacy right, and so Eisenstadt $v$. Baird, ${ }^{20}$ an equal protection case that overturned a statute regulating the distribution of contraceptives, might seem that right's real basis. But, like Griswold, Eisenstadt invoked a modest test-that a classification "must be reasonable, not arbitrary, and must rest upon some ground of difference having a fair and substantial relation to the object of the legislation,

12. Pierce v. Society of Sisters, 268 U.S. 510,535 (1925).

13. 316 U.S. 535 (1942).

14. Id. at 541 .

15. 321 U.S. 158 (1944).

16. Id. at 167 . The presence in the opinion of language generous to the view that parents have important rights over their children's well-being makes it easy to forget that Prince actually affirmed the conviction of a guardian who had taken her ward to sell the Watch Tower in violation of child-labor laws. Prince did so because of the state's expansively described interest in "the healthy, well-rounded growth of young people into full maturity as citizens, with all that implies." Id. at 168 .

17. 381 U.S. 479 (1965). Griswold was preceded by Justice Harlan's influential dissent in Poe v. Ullman, 367 U.S. 497, 522 (1961), a case in which the Court disposed on standing grounds of a challenge to the same statute prohibiting the use of contraceptives that was reviewed in Griswold. Justice Harlan reached the substantive question and wrote,

The statute must pass a more rigorous Constitutional test than that going merely to the plausibility of its underlying rationale. ... This enactment involves what ... must be granted to be a most fundamental aspect of "liberty", . . and it is this which requires that the statute be subjected to "strict scrutiny". Skinner v. Oklahoma, [316 U.S. 535, 541 (1942)] . . .

367 U.S. at 548 (Harlan, J., dissenting).

18. 377 U.S. 288,307 (1958).

19. 381 U.S. at 485.

20. 405 U.S. 438 (1972). 
so that all persons similarly circumstanced shall be treated alike."21 Perhaps significantly, it was not until Roe v. Wade, ${ }^{22}$ analytically the most problematic and politically the most controversial of the Court's privacy cases, that the "modern" test was used: "Where certain 'fundamental rights' are involved, the Court has held that regulation limiting these rights may be justified only by a 'compelling state interest,' . . . and that legislative enactments must be narrowly drawn to express only the legitimate state interests at stake."23

The modern test is not only novel, it is even now not invariably used. In Zablocki v. Redhail, ${ }^{24}$ for example, the Court considered a statute which required that any non-custodial parent under a support order who wished to marry show that he had complied with the support order and that his children were not then and were not likely to become public charges. This statutory impediment to marriage seemed, as such, to call for the modern standard of review. However, the Court used a weaker test: "Since our past decisions make clear that the right to marry is of fundamental importance, and since the classification at issue here significantly interferes with the exercise of that right, we believe that 'critical examination' of the state interests advanced in support of the classification is required." 25

As Zablocki indicates, the Court sometimes fails to invoke the standard its own doctrine seems to call for. At other times, the Court enunciates no standard at all. ${ }^{26}$ In both situations, explicitly or implicitly, the Court often seems to be using standards somewhere between the classic rational-basis and compelling-state-interest standards. The Court's struggles have been particularly evident in two kinds of cases. The first consists of cases involving post-Roe statutes that regulate but do not prohibit abortions. Consider, for instance, some of the earlier cases in that series. In Doe v. Bolton, ${ }^{27}$ Roe's companion case, the Court never avowedly adopted a test, but it repeatedly used language-"reasonably related," "legitimately related," "rational connection"-hinting though not establishing that it thought the rationalbasis standard appropriate. In Planned Parenthood of Central Missouri v. Danforth ${ }^{28}$ the Court again failed to identify the test it was applying and again

21. Id. at 447 (quoting Reed v. Reed, 404 U.S. 71, 75-76 (1971) (in turn quoting Royster Guano Co. v. Virginia, 253 U.S. 412,415 (1920))).

22. 410 U.S. 113 (1973).

23. Id. at 155. Before it decided Roe, the Court decided Wisconsin v. Yoder, 406 U.S. 205 (1972), and again used a test whose articulation suggested that it was less strict than the modern test: "[A] State's interest in universal education, however highly we rank it, is not totally free from a balancing process when it impinges on fundamental rights and interests . .." Id. at 214. More strictly, however, the Court also said that "only those interests of the highest order and those not otherwise served can overbalance legitimate claims to the free exercise of religion." Id. at 215 . The Court acknowledged that parental "privacy" rights were involved, but did not enunciate a separate test for them.

24. 434 U.S. 374 (1978).

25. Id. at 383. Even using this less rigorous standard of review, however, the Court found the statute unconstitutional.

26. See, e.g., Whalen v. Roe, 429 U.S. 589 (1977); Thornburgh v. American College of Obstetricians \& Gynecologists, 476 U.S. 747 (1986).

27. 410 U.S. 179 (1973).

28. 428 U.S. 52 (1976). 
used language-"unreasonable or arbitrary" - consistent in principle with a rational-basis test. In Carey $v$. Population Services International, ${ }^{29}$ however, the Court described the post-Roe cases as holding unconstitutional

statutes that did not prohibit abortions outright but limited in a variety of ways a woman's access to them. ... The significance of these cases is that they establish that the same test must be applied to state regulations that burden an individual's right to decide to prevent conception or terminate pregnancy by substantially limiting access to the means of effectuating that decision as is applied to state statutes that prohibit the decision entirely. Both types of regulation "may be justified only by a "compelling state interest' ...."30

In Akron v. Akron Center for Reproductive Health, ${ }^{31}$ the Court again confronted the standards problem. It said that "restrictive state regulation of the right to choose abortion ... must be supported by a compelling state interest." 32 But it also said that "[c]ertain regulations that have no significant impact on the woman's exercise of her right may be permissible where justified by important state health objectives." 33 And it added that, after the first trimester, the state " 'may regulate the abortion procedure to the extent that the regulation reasonably relates to the preservation and protection of maternal health.' "34

I will not weary the reader by trying to work out whether all these varying standards can in some technical way be reconciled with each other or with the assumptions of fundamental-rights analysis. It is perhaps enough to say that these tests have not been coherently applied in subsequent post-Roe cases (although the standard of review seems to be tightening). Indeed, in the recent case of Thornburgh v. American College of Obstetricians and Gynecologists, ${ }^{35}$ the Court once again neglected to announce which test it planned to apply. And further complicating the issue, now as before, the question whether the standard the Court invokes is the standard the Court actually uses in resolving these cases.

The other category of cases in which the Court has particularly struggled to find a state-interest standard consists of cases involving nonstandard rightholders like minors and prisoners. In Carey $v$. Population Services International, ${ }^{36}$ a case involving access to contraceptives by both minors and adults, the Court began by invoking the compelling-state-interest test but later wrote, "State restrictions inhibiting privacy interests of minors are valid only if they serve 'any significant state interest ... that is not present in the case of an adult." "37 In Bellotti $v$. Baird, ${ }^{38}$ the Court asked whether a parental consent statute

29. 431 U.S. 678 (1976). Carey, though, was a contraception, not an abortion, case.

30. Id. at 688 .

31. 462 U.S. 416 (1983).

32. Id. at 427 .

33. $J d$. at 430 .

34. Id. at 430-31 (quoting Roe v. Wade, 410 U.S. 113, 163 (1973)).

35. 476 U.S. 747 (1986).

36. 431 U.S. $678(1977)$.

37. Id. at 693 (quoting Planned Parenthood of Missouri v. Danforth, 428 U.S. 52, 75 (1976)). The Court added, "This test is apparently less rigorous than the 'compelling state interest' test applied to restrictions on the privacy rights of adults." Id. at 693 n.15.

38. 433 U.S. 622 (1979). 
"unduly burden[ed]" the minor's right to seek an abortion. ${ }^{39}$ And the Court in H.L. v. Matheson ${ }^{40}$ upheld a parental notification requirement against a minor's constitutional challenge because it "serves important state interests, is narrowly drawn to protect only those interests, and does not violate any guarantees of the Constitution." 41 Finally, in Turner $v$. Safley, ${ }^{42}$ a case involving the right of prison inmates to marry, the Court, emphasizing that it was dealing with a "prisoner's rights" case, said that a regulation severely limiting a prisoner's right to marry "is valid if it is reasonably related to legitimate penological interests." 43 In short, the announced standard in cases involving nonstandard rightholders is at least as volatile as the standard in the post-Roe cases, and the doubts about the correspondence between the test invoked and the test actually used are at least as pronounced.

The novelty of the "modern" test and the inconstancy of its application are perhaps not astonishing, given the novelty and uncertain scope of the privacy doctrine itself. In any event, the inconstancy should be measured against the baseline of inconstancy that is common in legal doctrines in complex and controversial areas. Furthermore, the degree of inconstancy has in one sense been moderated (albeit confusingly) by the Court's occasional willingness to announce a relatively mild test while actually applying the modern test. ${ }^{44}$ However, the novelty and inconstancy of the modern test are noteworthy because they give us our first hint of the extraordinary difficulty of state-interest analysis in fundamental-rights privacy cases. That difficulty can begun to be understood by briefly exploring some of the reasons for the novelty and inconstancy. I infer that the modern test was late in coming and that it is sometimes ignored because of two factors: first, the Court's uncertainty about the right to privacy itself and about how far it may take the Court; second, the Court's unwillingness to treat state interests as strong enough to overcome rights.

The Court's uncertainty about the right of privacy is evidenced by the continuing obscurity of the term "privacy" and of the right that term describes. The Court has avoided defining the right; rather, it has preferred to proceed analogically. The right is most easily rationalized in broad Millian terms, and commentators have widely done so. ${ }^{45}$ The Court, however, has not; ${ }^{46}$ but neither has it provided an alternative interpretation. Some of the Court's reluctance to define the privacy right may spring from the fact that

39. Id. at 640 .

40. 450 U.S. 405 (1981)

41. Id. at 413 .

42. 107 S. Ct. 2254 (1987).

43. Id. at 2261 .

44. Eisenstadt v. Baird, 405 U.S. 438 (1972), and Zablocki v. Redhail, 434 U.S. 384 (1978), come readily to mind. This willingness to announce one standard while applying another is not uncommon in equal protection cases. See, e.g., Cleburne v. Cleburne Living Center, 473 U.S. 432 (1985).

45. For a survey of commentators, see Grey, Eros, Civilization and the Burger Court, LAw \& Contemp. Probs., Summer 1980, at 83

46. See, e.g., Bowers v. Hardwick, 478 U.S. 186 (1986); Grey, supra note 45; Burt, The Constitution of the Family, 1979 SuP. CT. REv. 329. 
attempts to define it must provoke an unwelcome re-examination of many complex and controversial questions about constitutional interpretation and judicial review. The heart of the problem, though, is probably that privacy is a "greedy" concept 47 whose core principle seems endlessly expansive. The Court itself slips easily into paraphrasing the privacy right as the even broader "right to be let alone." The unconfrontable problem, then, becomes finding principles to limit the right of privacy. ${ }^{48}$ Those limiting principles cannot be found in the text of the Constitution (since it never speaks of a right to privacy) nor in the intent of the Framers of the fourteenth amendment (since they did not contemplate a right to privacy) nor in a judicial definition of the right of privacy (since the Court has not seriously attempted to construct one). Indeed, the Court has rejected one limiting principle-the idea that privacy is the right to do what you want with your own body-because it was not limiting enough. ${ }^{49}$ Nevertheless, the need for limiting principles is palpable: the right to be let alone is ultimately the right not to be governed.

The absence of a limiting principle has apparently concerned the Court in at least two respects. First, the Court has long anticipated that some family law regulations-like those prohibiting sodomy-seem to affront core privacy principles but are so deeply rooted in American history, law, moral belief, and popular sentiment that the Court will not overturn them. ${ }^{50}$ Second, family law regulates some parts of family life extensively yet unproblematically. As the Court wrote in Zablocki:

By reaffirming the fundamental character of the right to marry, we do not mean to suggest that every state regulation which relates in any way to the incidents of or prerequisites for marriage must be subjected to rigorous scrutiny. To the contrary, reasonable regulations that do not significantly interfere with decisions to enter into the marital relationship may legitimately be imposed. 51

Yet in the absence of a limiting principle to privacy, it is hard for the Court to explain why the privacy doctrine should not be applied with its usual severity in both areas, or indeed in many others.

The lack of a definition of and limiting principles to the privacy doctrine puts pressure on state-interest analysis, since one obvious solution to the problem of a too-expansive privacy doctrine is to allow the state interests in such regulations to override the privacy right. For instance, one solution to the uncertain dimensions of the rights of nonstandard right-bearers would be to acknowledge a state interest either in protecting the right-bearers (as with minors) or in protecting society against the right-bearers (as with prisoners). That solution, however, has been barred by the virtually outcomedeterminative nature of the question whether a fundamental right is at stake. That is, in the privacy context, the modern test has proved so strict that a

47. Freund, Privacy, in Privacy (Nomos XIII) (J. Pennock \& J. Chapman eds. 1971).

48. See Schneider, supra note 3; Note, supra note 8.

49. Roe v. Wade, 410 U.S. 113,154 (1973).

50. See Bowers v. Hardwick, 478 U.S. 186 (1986).

51. 434 U.S. 384,386 (1978). 
statute that must meet it stands little chance of being found constitutional. 52 The Court's slowness to adopt and reluctance to adhere to the modern test may, then, have been an attempt to preserve flexibility in handling the intricate and puzzling problems with which family law deals while retaining the two-tier test and its accompanying doctrinal tools. ${ }^{53}$

The two-tier test has been much assailed by academics and judges because of its rigidity, and in equal protection cases the Court has responded to the problem by adopting a third tier of intermediate scrutiny. ${ }^{54}$ I have tried to show how, in the privacy area, that rigidity indeed exists and indeed has driven the Court to doctrinal confusion and sub rosa adjustments of its standards. However, the two-tier approach has virtues, and its alternatives have faults. Its first virtue is that it is professedly an attempt to limit the damage done to the majoritarian principle by judicial review, since its purpose is to preserve a large area within which legislatures have the considerable liberty granted them by the rational-basis standard. The two-tiered approach's second virtue is that it promotes simplicity and predictability of decision. The primary alternative to the two-tiered approach, on the other hand, is to balance the right against the state interest case by case. Since personal rights and state interests are incommensurable, it is hard to see what

52. Roe $\mathrm{v}$. Wade was the only privacy case in which a state successfully asserted that its interests were compelling. When the Court has wished to uphold a regulation, it has generally done so by interpreting the right narrowly rather than finding that the state interest overcomes the right. In Maher v. Roe, 432 U.S. 464 (1977), for instance, the Court upheld a state regulation permitting Medicaid payments only for "medically necessary" abortions. The Court avoided applying the modern test by concluding "that the Connecticut regulation does not impinge upon the fundamental right recognized in Roe." Id. at 474. And, in Bowers v. Hardwick, 478 U.S. 186 (1986), the Court sustained a state law prohibiting homosexual sodomy. The Court avoided applying the modern test by interpreting the earlier privacy cases and concluding that those cases would not "extend a fundamental right to homosexuals to engage in acts of consensual sodomy." Id. at 192. For information about the larger background of these issues, see Professor Gunther's influential. discussion of the two-tier problem in the context of equal protection. Gunther, supra note 8.

53. The rigidity of substantive-due-process analysis contrasts illuminatingly with the comparative flexibility of procedural-due-process analysis. As we have seen, a finding that a statute conflicts with a substantive fundamental right generally means the statute will be held unconstitutional. In contrast, comparatively little need turn on the finding of a right to procedural due process: The Court has often interpreted the requirements of due process flexibly, in ways that are relatively sensitive both to the variety of personal interests at stake and to the different institutional contexts in which the state acts. Thus, instead of invariably requiring trial-like procedures, the Court has held, for example, that the ordinary admittance and retention procedures of a state mental hospital could provide due process to children involuntarily committed by their parents. Parham v. J.R., 442 U.S. 584 (1979).

The standard criteria for evaluating due process issues make the flexibility of procedural-dueprocess analysis plain, for in determining what process is due, the Court overtly weighs the private interests, the governmental interest, and the risk that the procedures in use will produce incorrect decisions. Mathews v. Eldridge, 424 U.S. 319 (1976). The flexibility of due process lies not only in the freedom it allows in shaping remedies to the nature of the right, but (somewhat less attractively) in the fact that it often allows courts to avoid making hard decisions about the scope of the right. See Smith v. Organization of Foster Families for Equality \& Reform, 431 U.S. 816 (1977). Of course, the Court need not use this flexibility. See Santosky v. Kramer, 455 U.S. 745 (1982). Similarly, one advantage (the virtue of its fault) of the Lochner era's formulation of the state-interest test (a "reasonable relation to some purpose within the competency of the state") was that it gave courts a flexibility that modern substantive-due-process law does not.

54. See Shaman, Cracks in the Structure: The Coming Breakdown in the Levels of Scrutiny, 45 Oнго Sт. L.J. 161 (1984). 
principle would guide courts if balancing were substituted for two-tier analysis, and one supposes pressure would build to develop such a principle. Since commentators have not proffered a principle, one wonders how much of an improvement it might be. Furthermore, ad hoc balancing offers no institutionalized protection for the majoritarian principle, and for that matter, offers no institutionalized protection for the right to privacy. ${ }^{55}$

In sum, then, we have seen in this part a Court struggling to find a standard to apply in state-interest analysis. We have seen that even when the Court articulated a standard, it could not bring itself to apply it consistently. We have seen that these problems derive from the inability of the Court to define the doctrine of privacy and to infer from the definition a limiting principle. The absence of such a principle puts considerable pressure on state-interest analysis to provide limits on the privacy doctrine. How well state-interest analysis responds will depend in part on the clarity and usefulness of the terms its test employs. To that subject we now turn.

\section{B. The Uncertain Meaning of the Standard's Terms}

I have been arguing that the first difficulty with the Supreme Court's stateinterest analysis has been its ambivalence in selecting a standard of review. The second difficulty is its unwillingness to define the standard's component terms. The first of these terms, of course, is that the legislation be "necessary" to serve the state interest. But what is necessary? How effective, for example, does the statute have to be? Effective as compared to what? As compared to the normal run of statutes, or as compared to some absolute standard? How is effectiveness to be measured? Given the state of the social sciences and the limits of social resources, can effectiveness be measured? Because "necessary" is undefined, questions of this sort could be multiplied indefinitely. In the absence of definitions, then, we must turn to the Court's holdings to construe the term's meaning.

In privacy cases, the Court has largely handled questions of "necessity" not by directly assessing a statute's effectiveness, but rather by devising and deploying two categories of "non-necessity." In the first of these categories, the Court finds that a statute is not "necessary" because some alternative and constitutionally inoffensive statute would serve the state's purpose. In principle, this formula is appealing. In practice, there have been important unanswered questions. How far, for instance, does the state have to go to find alternatives? How is the effectiveness of the alternative to be judged? What if the alternative would cost substantially more, either economically or socially? What if it would work less well? What if its chances of success are purely

55. Professor Gunther's solution, see supra note 8 , is to allow for rational-basis scrutiny with bite, but to allow the court only to evaluate means, not ends. This solution has the virtue of relieving courts of the problem of comparing incommensurables and of providing some institutionalized protection for the majoritarian principle. However, courts would still be left with the difficulties of evaluating means which I will describe in part II.B, infra, and, since virtually every statute that has been invalidated on privacy grounds was invalidated on means and not ends grounds, his proposal might make little difference in privacy cases. 
speculative? Because the Court does not examine alternatives with anything like the energy it devotes to challenged statutes, we are hard put to answer such questions.

The difficulty with the "alternatives" principle in the privacy context has in part to do with a particular feature of family law: In it, enforcement problems are as pervasive and intractable as anywhere in the law. ${ }^{56}$ The severity of these enforcement problems makes the availability of alternatives less meaningful and may make necessary the cumulative use of several kinds of enforcement measures. For example, in Zablocki 57 the Court said that "the State already has numerous other means for exacting compliance with support obligations, means that are at least as effective as the instant statute's and yet do not impinge upon the right to marry." 58 The Court listed wage assignments, civil contempt proceedings, and criminal penalties. ${ }^{59}$ These alternatives were in fact part of Wisconsin's law, but they had been notably ineffective. ${ }^{60}$ Even the most vigorous, systematic, and successful states do badly at enforcing child-support obligations. ${ }^{61}$ Further, many statutes attempt to deal with several related social problems at once. A satisfactory alternative should presumably deal with all the problems the challenged statute dealt with. For instance, the alternatives to the Zablocki statute (wage assignments, civil contempt proceedings, and criminal penalties) all were aimed at men who could afford to pay but refused to; the Zablocki statute, on the other hand, tried in part to prevent men from becoming unable to pay their current child support because they had assumed new financial responsibilities and in part to prevent men from incurring new child-support

56. For a brief summary of the multitude of reasons for this, see Schneider, The Next Step: Definition, Generalization, and Theory in American Family Law, 18 U. MICH. J. L. REF. 1039, 1056 (1985).

57. For a description of Zablocki, see supra text accompanying note 24.

58. 434 U.S. 374,389 (1978).

59. Id. at 390. The Court never asked whether, since the successful enforcement of the financial obligations (like alimony or child support) of one marriage would also presumably deter some people from taking on similar new obligations, these alternatives might also "impinge upon the right to marry."

60. Ironically, the first major study of child-support enforcement policies investigated Dane County, Wisconsin (the county containing Madison, the state capital). Eckhardt, Social Change, Legal Controls, and Child Support: A Study in the Sociology of Law (Ph.D. diss., University of Wisconsin 1965). As Professor Chambers reports,

Eckhardt found that in the first year under the support order, 40 percent of fathers made no payments whatever. By the seventh year, over 70 percent were making no payments. Over the seven-year period, the mean level of payments by all fathers seems to have been no higher than about 30 percent of everything they owed.

D. Chambers, Making Fathers Pay 72 (1979).

61. In Genesee County, Michigan, an unusually successful county in an unusually successful state (an administrative agency, the Friend of the Court, helps pursue delinquents, and courts use jail readily), $24 \%$ of the fathers who owed child support were paying $10 \%$ or less of the ordered amount in the sixth year of the order; $18 \%$ were paying between $10 \%$ and $80 \%$; and $58 \%$ were paying $80 \%$ or more of the ordered payment. D. Chambers, supra note 60, at 77 . Using the world, not the United States, as the point of comparison, one scholar concludes that "even a very efficient support system has its limits .... About 15 percent of Swedish divorced parents liable for support pay nothing, while 25 percent pay less than 30 percent of what they owe." M. GLENDON, ABORTION AND Divorce in Western law: American Failures, European Challenges 88-89 (1987). 
obligations which they could not meet. ${ }^{62}$ In short, alternatives are rarely likely to be fully satisfactory substitutes. Indeed, even the challenged statutory device and all the alternatives combined may often not fully achieve the legislative purpose (or, more often and more problematically, purposes). In that sense, the challenged device may indeed be a necessary, if only incremental, step. ${ }^{63}$

The Court's second (and related) category of "non-necessity" has to do with "fit" (with whether a legislative classification is over- or underinclusive). Fit, of course, is an idea used primarily in equal-protection analysis, where the absence of fit may indicate that one group has been singled out for special benefits or burdens. However, fit works awkwardly in fundamental-rights cases, even when, as in Eisenstadt and Zablocki, fundamental-rights analysis is clothed in the garb of equal protection. True, the "overinclusiveness" part of fit analysis may in principle be appropriate. A statute that infringes fundamental rights more broadly than is truly necessary to accomplish all the state's purposes surely is undesirable. ${ }^{64}$ But "underinclusiveness," while relevant to equal-protection analysis because it hints that a favored group is excusing itself from the burden of a statute, seems irrelevant to privacy cases. Consider, for example, the underinclusiveness argument in Zablocki. There, the Court noted that the statute "does not limit in any way new financial commitments by the applicant other than those arising out of the contemplated marriage." 65 But why is this troublesome? Quite aside from the many reasons for singling out the costs arising out of a contemplated marriage, ${ }^{66}$ why is it a fault that the statute does not go as far in restricting

62. It was presumably also aimed at compelling regular payment by divorced men who wished to remarry or to be free to do so.

63. Zablocki reveals another problem with means analysis: the difficulty of measurement. Means analysis requires, in principle, that courts be able to decide whether a statute is effectively serving its purpose. But even under the best of circumstances, this inquiry will be brutally difficult. Suppose that a statutory prohibition is never violated. It will be impossible to say that the statute is successful because it will be impossible to say that the people would not have behaved as they were directed to even in the absence of a statute. Suppose, on the other hand, that a statutory prohibition is often violated. It will be impossible to measure the effect of the statute because there will be no way of knowing whether even more people would have behaved even more undesirably in the absence of a prohibitory statute. For example, a failure to punish the improper behavior might have encouraged improper behavior by allowing people to think that, because the behavior was not punished, it was not disapproved. These problems may be particularly acute in an area like Zablocki's, since a widespread sense that other ex-husbands are not keeping up their payments might lead men to ask, "Why should I pay if nobody else does?" To put the point differently, one important, but unmeasurable, function of a statute may be to reinforce the beliefs and behavior of those who are already acting properly.

64. It is not clear that the "overinclusiveness" problem is different from the "alternatives" problem. Thus, the same limits to the "alternatives" approach I catalogued above may apply to "overinclusiveness" approaches.

65. 434 U.S. 374, 390 (1978).

66. Costs arising out of a contemplated marriage might be singled out for special treatment because, for example, (1) they are likely to be specially great, (2) they are likely to be costs which last a particularly long time, (3) they are likely to be costs which cannot and ought not be escaped, and (4) they are costs that it is particularly easy for the state to regulate through its control over marriage licenses. Furthermore, the prohibition in Zablocki was presumably designed not just to protect the delinquent's existing children and former spouse, but to protect the delinquent's future children and future spouse. The regulation seems neatly tailored for that purpose, enforcement problems aside. 
liberty as it might? What would a statute that was not underinclusive look like? Would it not be socially and perhaps constitutionally more offensive than the challenged statute?67

Problems with using fit also arise when the Court assesses each of a statute's several purposes without considering the ways in which the legislature must moderate its pursuit of one goal in order to serve others as well. This is what Professor Nagel, in his incisive student note, calls the "divide and conquer" tactic. ${ }^{68}$ His analysis of Eisenstadt $v$. Baird illustrates this flaw in "fit" reasoning. The Massachusetts statute in Eisenstadt prohibited the distribution of contraceptives except for prophylactic purposes or except to married couples by prescription. The Court said that the statute was discriminatory and overbroad because, "[i]f there is a need to have a physician prescribe ... contraceptives, the need is as great for unmarried persons as for married persons.' "69 But, Professor Nagel observes, another purpose of the statute was to discourage premarital sex, which accounts for the different treatment of the married and unmarried. The Court noted further that some contraceptives were available if they could be used for prophylaxis. Professor Nagel responds that this was not evidence of the statute's insincerity, as the Court seemed to think, since the statute sought to restrict access to contraceptives only insofar as that was consistent with another statutory purpose-promoting public health. Finally, the Court held that the statute violated the equal protection clause because of the exception for married couples. Professor Nagel argues, however, that this exception was drawn in recognition (probably constitutionally required after Griswold $v$. Connecticut) of the right to marital privacy. In sum, Professor Nagel concludes that, by testing the statutory purposes in isolation from each other, the Court missed the complexity of the true statutory purpose and therefore could not properly evaluate whether the statute's means fit its ends:

The legislature's overall purpose might have been defined as follows: to discourage premarital sex by making contraceptives harder to obtain to the extent that this would not increase the risks of venereal disease; to provide for the medical supervision of the distribution of contraceptives to the extent that this would not increase the availability of contraceptives to the unmarried; and to discourage the use of contraceptives to the extent that this would not interfere with the private behavior of married persons. Unless it is "irrational" per se for a legislature to design a statute to achieve a set of somewhat conflicting policy objectives, the Massachusetts statute would appear to have been rational. ${ }^{78}$

Having glimpsed some of the difficulties of defining "necessary," let us move now to the second undefined term in the Court's standard for deciding privacy cases-the requirement that statutes infringing privacy rights serve a

67. The Court has used "fit" reasoning in similarly puzzling ways in other areas. See Schneider, Free Speech and Corporate Freedom: A Comment on First National Bank of Boston v. Bellotti, 59 S. CAL. L. REv. 1227, 1285-86 (1986).

68. Note, Legislative Purpose, Rationality, and Equal Protection, 82 Yale L.J. 123, 127 (1972).

69. 405 U.S. 438, 450 (1972) (quoting Commonwealth v. Baird, 355 Mass. 746, 758, 247 N.E.2d 574, 581 (1969) (Whittemore \& Cutter, J.J., dissenting)).

70. Note, supra note 68 , at 127-28. 
"compelling state interest." What is "compelling"? The term has no intrinsic meaning. On the contrary, it is classically a term of imprecision in literary criticism, the term critics use when they liked the book, but can't quite figure out why. Yet the Court has sedulously avoided defining it. Of course, judges frequently leave the definition of a test to case law which gradually reveals and refines the test's meaning. However, since Roe $v$. Wade is the only privacy case that acknowledged a compelling state interest, we are left with the information that protecting a pregnant woman's health after the first trimester and protecting fetal life after the second trimester are compelling state interests. But since the Court barely explains why these are compelling state interests or why each interest is not compelling at an earlier stage of pregnancy, ${ }^{71}$ we are left with only a shallow understanding of "compelling" state interests.

It might, of course, be thought that the kinds of statutes at issue in privacy cases are simply unlikely ever to implicate state interests of any significance, that they are mere attempts to "legislate morality."72 But that is not so. The purpose of the statute overridden in Zablocki, for instance, was in part to improve the often intolerable circumstances of divorced women and their children. Recent evidence suggests that, even where former husbands faithfully make alimony and child-support payments, former wives and their children are more severely disadvantaged economically by divorce than their former husbands. ${ }^{73}$ And since those payments are widely not made, the state's interest in alleviating their misery is urgent. ${ }^{74}$ In Roe v. Wade, to take an example of a different sort, it was not easy to understand why the scope of the "compelling" state interest was not even greater than the Court conceded. The Court there said that fetal life in the first two trimesters is "potential life." It did not explain why potential human life may not be of compelling interest

71. The Court's explanations of when both interests become compelling may be given in their entirety:

With respect to the State's important and legitimate interest in the health of the mother, the "compelling" point ... is at approximately the end of the first trimester. This is so because of the now-established medical fact ... that until the end of the first trimester mortality in abortion may be less than mortality in normal childbirth.

Roe v. Wade, 410 U.S. 113, 163 (1973). Yet it is hard to see why that medical fact indicates that the state does not have an interest in preventing whatever mortality and whatever morbidity may occur in first trimester pregnancies.

With respect to the State's important and legitimate interest in potential life, the "compelling" point is at viability. This is so because the fetus then presumably has the capability of meaningful life outside the mother's womb.

Id. at 163. We are not told, however, what "meaningful" means or why fetal life before the third trimester-which the Court stipulates is at least "potential life"--may not be of compelling interest to the state.

72. For a brief comment on whether "legislating morality" is a legitimate state interest, see infra note 93 and accompanying text.

73. See generally D. Chambers, supra note 60; L. Weitzman, The Divorce Revolution: The Unexpected Social and Economic Consequences for Women and Children in America (1985); T. Arendell, Mothers and Divorce: Legal, Economic, and Social Dilemmas (1986).

74. The Court in Zablocki, of course, did not say that these interests were not important; it did not reach that question, since it found the statute "unnecessary" to serve the state purpose. 434 U.S. at 388 . 
to a state (nor did it satisfactorily explain why a state could not reasonably conclude that it was protecting not just potential, but actual, human life). Since the law usually regards human life as the ultimate value, such an explanation seems called for. To take a final kind of example, in some privacy cases the state interest is to effectuate privacy rights that might otherwise be destroyed. In Planned Parenthood of Central Missouri v. Danforth, ${ }^{75}$ for instance, the Court held unconstitutional a statute that required minors to have parental consent to an abortion. The Court saw the requirement as the delegation of a state veto to the parents, and thus as unconstitutional. But the parents' interest in directing the upbringing and defining and ensuring the welfare of their children is itself a fundamental right and therefore, one might suppose, a compelling state interest. ${ }^{76}$

The ambiguities I have been discussing are aggravated by the uncertainty whether "compelling" is an absolute or a relative term. That is, may the strength of the state interest vary with the strength of the fundamental right, so that a weak fundamental right may be infringed by a weak compelling state interest? Similarly, is "necessary" an absolute term, or does it vary with the strength of the right or with the strength of the state interest? The language of the test suggests that these terms are not relative, that an interest is either compelling or it isn't, that a statute is either necessary to serve an interest or it isn't. Moreover, the Court has never avowedly treated "compelling" or "necessary" as relative terms, and when it has wished to uphold a statute, it has struggled to find that no fundamental right is affected and thus that the question whether the state's interest is compelling may be avoided, a struggle that might often be unnecessary were the test's terms relative. ${ }^{77}$ Finally, making "necessary" and "compelling" absolute and not relative terms helps courts escape balancing the right against the state interest, a consumation devoutly to be wished, given that the two are incommensurable.

Nevertheless, it is easy to think that, particularly in an area of regulation as intricate as family law, some exercises of a fundamental right will be trivial and ought to be regulable with only modest justification. This, indeed, is what the quotation from Zablocki (that not "every state regulation which relates in any way to the incidents of or prerequisites for marriage must be subjected to rigorous scrutiny") implies. ${ }^{78}$ Further, the Court in Roe $v$. Wade seemed to be using just such a sliding scale in its scheme of increasing levels of permissible regulation in each succeeding trimester. Finally, cases involving minors and

75. 428 U.S. 52, 72-75 (1976).

76. On similar grounds, the Court in Danforth invalidated a spousal-consent provision. If such a provision is seen not as the delegation of state power but, as Justice White saw it in dissent, 428 U.S. at 93, as the state's recognition of the father's privacy right in making decisions about procreation, then, given the importance the Court has attributed to such rights, the state's interest seems compelling. This kind of state interest (that is, an interest in promoting the privacy rights of one among several competing individuals) is particularly likely to arise in cases involving conflicts between parents and children. E.g., Wisconsin v. Yoder, 406 U.S. 205 (1972). I discuss the frequency of such conflicts and the dilemmas they represent in Schneider, supra note 3.

77. See supra note 52 and accompanying text.

78. 434 U.S. 374,386 (1978). 
prisoners can be understood as allowing heightened state regulation because of the relatively weak privacy rights involved. In short, there are reasonable arguments on both sides of the question whether "compelling" and "necessary" are relative terms, a fact which exacerbates the ambiguities I have been describing.

These doubts about whether the terms of the test are relative or absolute go back once again to the Court's failure to define the privacy right. That right apparently encompasses widely various kinds of situations (from entry into marriage, to parental decisions about children's education, to abortion), and even within a single situation the nature and intensity of the personal interest can vary radically. If "necessary" and "compelling" are absolute terms, the Court must encounter the awkward problem of dealing with fundamental rights that protect both vital and trivial personal interests. In contrast, consider equal protection cases involving race. The country's historical experience with racial discrimination, the harshness of the need to repudiate that experience, and the cruel injury racial discrimination inflicts provide some common level of seriousness to equal protection rights. That commonality makes it plausible to require a compelling state interest whenever a statute infringes the equal protection rights of a racial minority. The absence of any such commonality makes that standard awkward in privacy cases when relatively modest interests are defended with the full arsenal of a fundamental right.

In sum, state-interest analysis in fourteenth amendment privacy cases has been marked by repeated failures of definition, by failures to define either a standard or its component terms. These failures bespeak, I think, the Court's unwillingness or inability to decide what it meant to do when it began to constitutionalize family law, the difficulties of setting coherent yet reasonably simple and workable judicial policy in an area as multifarious as family law and in a country as various as ours, and the problems with assessing the desirability and effectiveness of legislation in family law. At the last of these, we now take a closer look.

\section{The Uncertain Handling of Empirical Evidence}

I observed above that the absence of a limiting principle to the right to privacy puts pressure on state-interest analysis, which takes on most of the burden of limiting that right. Our study of the terms of the Court's test for evaluating state interests concluded, however, that state-interest analysis as the court developed it is ill-equipped to sustain that pressure. Thus, the weakness of state-interest analysis in turn puts pressure on the definition of the fundamental right. Nevertheless, if the Court's handling of each case were probing and perceptive, these reciprocal pressures might be somewhat alleviated. The Court's performance, however, has generally been clumsy and obtuse. My criticisms here have particularly to do with the Court's treatment of empirical problems. Showing that a statute isn't "necessary" to promote the legislature's purpose raises empirical questions of the most elaborate and 
perplexing kind. Yet the Court consistently prefers a priori reasoning to marshalling and analyzing empirical evidence. I believe this problem is important, but since I have explored the Court's aversion to empirical evidence elsewhere, ${ }^{79} \mathrm{I}$ will not expatiate on it here.

There are, of course, many reasons for the Court's perfunctory and dismissive treatment of empirical issues. The most sympathetic is that social scientists often have not studied a problem, or have not studied it in ways that speak to the policy issues courts confront. Another sympathetic reason is that the issues are so complex and impenetrable that even skillful studies commonly produce tentative, partial, and unhelpful results. ${ }^{80}$ Further, lawyers often fail to adduce what social science evidence there is, and courts are generally unequipped to use it well. ${ }^{81}$ But courts also are crippled by what I have called their hyper-rationalism-"the belief that reason can reliably be used to infer facts where evidence is unavailable or incomplete." 82 More specifically:

In its first aspect, [hyper-rationalism] is the assumption that systematic evidence is generally superfluous to understanding social problems, since the behavior of people and institutions can be logically inferred from a general understanding of how people and institutions work. In its second aspect, it is the assumption that, in the absence of a general understanding of how people and institutions work, anecdotal evidence is generally sufficient, since the behavior of people and institutions can be logically inferred from a few examples of their actual behavior under the relevant circumstances. In its third aspect, it is the assumption that a description of social reality articulated in one case may be taken as demonstrated fact in subsequent cases; it is, in other words, the application of stare decisis to evidence about social behavior. ${ }^{83}$

In sum, the reciprocal pressure that a poorly defined privacy right and a poorly constructed state-interest analysis place on each other is exacerbated by the Court's regularly superficial and inept treatment of empirical problems. But to have concluded that the doctrinal structure of state-interest analysis is infirm leaves unremarked several further doctrinal weaknesses and a number of considerations that go beyond doctrine. To these and to their consequences for the constitutionalization of social issues we now turn.

79. Schneider, Lawyers and Children: Wisdom and Legitimacy in Family Policy, 84 Mich. L. REv. 919 (1986).

80. For two excellent reviews of the social science literature on issues relating to child-custody decisions, both reaching this kind of conclusion about the literature, see Ellsworth \& Levy, Legislative Reform of Child Custody Adjudication: An Effort to Rely on Social Science Data in Formulating Legal Policies, 4 LAw \& Soc'y REv. 167 (1969); Chambers, Rethinking the Rules for Custody Disputes in Divorce, 83 MICH. L. REv. 477 (1984). For an extended and thoughtful examination of the problems involved in designing and carrying out social science research intended to answer policy questions, see M. WALD, J. Carlsmith \& P. Leiderman, Protecting Abused and Neglected Children (1988).

81. See Davis, "There is a Book Out . . ".:An Analysis of Judicial Absorption of Legislative Facts, 100 HARV. L. REV. 1539 (1987).

82. Schneider, supra note 79 , at 932 .

83. Id. at $932-33$ (footnotes omitted). For a detailed and telling examination of how courts have dealt with empirical problems in various kinds of fourteenth amendment cases involving children, see R. Mnookin, R. Burt, D. Chambers, M. Wald, S. Sugarman, F. Zimrinc \& R. Solomon, In the InTERest of ChILdRen (1985), particularly part IV, which contains Professor Mnookin's incisive analysis of the judicial treatment of the policy issues in Bellotti v. Baird, $428 \mathrm{U} . \mathrm{S}$. 132 (1976). For an insightful and broader examination of rationalism in constitutional analysis, see Nagel, Rationalism in Constitutional Law, 4 Const. Comment 9 (1987). 
III

\section{A Different Perspective on State Interests: The Socializing Strategy}

In part II, I made three criticisms of the Court's state-interest analysis. These criticisms seem to me important not just on their own merits, but because each of them reflects serious difficulties with the principle of fourteenth amendment privacy. I now wish to investigate some of those difficulties from a different perspective by exploring more generally the kinds of justifications a state may legitimately advance in support of a statute said to violate a fourteenth amendment privacy right. My discussion begins with the general observation that the Court often looks at the particular situation a case presents in isolation from its legal and social context and often looks at the challenged statute in isolation from other statutes and from other forms of social regulation. Seen in these two, related, kinds of isolation, many of these statutes seem to serve weak, to say nothing of compelling, interests. Seen in these kinds of isolation, many of these statutes appear under- or overinclusive. But seeing these statutes in isolation is troublesome, for reasons that repay extended inquiry.

Let me illustrate the first kind of isolation-the isolation of the particular fact situation from its larger social setting-with a case from the Colorado Supreme Court. In Israel $v$. Allen, ${ }^{84}$ a brother and sister related only by adoption and not by blood wished to marry. Colorado law expressly forbad such marriages. The court's opinion began, "Since we find . . . that the provision prohibiting marriage between adopted children fails even to satisfy minimum rationality requirements, we need not determine whether a fundamental right is infringed by this statute." 85 The state had reasoned that the statute furthered an interest in "family harmony," but the court replied that, because there were no special genetic risks to such a marriage and because the " "natural repugnance of people toward marriages of blood relatives ... is quite generally lacking in application to the union of those related only by affinity," " there could be no logical reason for barring this couple from marriage. ${ }^{86}$ The court therefore ruled in favor of the brother and sister.

The Israel's "family harmony" may indeed have been undisturbed, but surely the state's argument was not addressed just to that particular family. Rather, the state presumably meant that "family harmony" in society generally was promoted by keeping the possibility of sexual relations between family members as far from their minds as possible..$^{87}$ In brief, the legislature sought to reinforce the incest taboo. It sought to do so by making marriage

84. 195 Colo. 263, 577 P.2d 763 (Colo. 1978).

85. Id. at 265,577 P.2d at 764 .

86. Id. at 764 (quoting I Vernier, American Family Laws 183 (1931)).

87. When one of my classes was discussing Israel, a student said (in a voice rich with discovery), "If I'd known brothers and sisters married each other, I would have looked at my brother in a whole different way." 
between any people in the relation of siblings entirely unthinkable, not just unthinkable for actual siblings. Taboos do not work rationally; they work by inducing reactions of horror and disgust at the prohibited practice. Rational analysis of taboos is not only likely to miss this point, but even itself to weaken the taboo. Once you begin to think about which kinds of incest-like activities lack particular identifiable harmful consequences for particular identifiable participants, you begin to think about the unthinkable and about why some "incest" is harmless incest. As this process continues, the emotional force of the taboo, its force as a general deterrent, is eroded. Thus, by failing to understand that the statutory prohibition was part of a larger social prohibition which served a larger social purpose than preventing the disruption of particular families, the court misunderstood the nature and mechanics of the state's interest and underestimated its strength (and its ultimate rationality)..$^{88}$

The second (and related) kind of isolation in which courts tend to see statutes-the isolation of statutes from their larger legal context-may be introduced by a more troublesome case, one in which the state's position seems merely anachronistic and the Court's position seems at least stronger than the court's in Israel. In Eisenstadt $v$. Baird, the Court confronted a Massachusetts statute prohibiting the distribution (not, as in Griswold, the use) of contraceptives. In considering the statute's justifications, the Court quoted a 1917 opinion of the Massachusetts Supreme Judicial Court which said that the law's " 'plain purpose is to protect purity, to preserve chastity, to encourage continence and self restraint, to defend the sanctity of the home, and thus to engender in the State and nation a virile and virtuous race of men and women." "89 The Court responded to this quaint avowal by noting that the statute allowed married couples access to contraceptives and by reasoning that Massachusetts could not have intended to make pregnancy a punishment for the mere misdemeanor of fornication. The Court thus found the statute unconstitutional. This was, no doubt, an uncommonly silly law. ${ }^{90}$ Nevertheless, the Court unduly limited its understanding of the state interest by seeing the statute in isolation.

The problem Eisenstadt illustrates is that a statute may be intended as part of a system of legal (and non-legal) regulation of social behavior. Family law, as I noted above, is distinguished by the ubiquity and intensity of its enforcement difficulties. Because family law regulates conduct that occurs in private, because regulating private conduct can produce undesired and undetectable consequences, and because familial conduct is often motivated by fiercely powerful drives, family law-traditionally and presently-operates

88. My argument is not intended to be dispositive of Israel. The remaining question is whether Martin and Tammy Israel should have to bear the (for them disproportionate) cost of maintaining the incest taboo.

89. Eisenstadt v. Baird, 405 U.S. 438,448 (1972) (quoting Commonwealth v. Allison, 227 Mass. $57,62,116$ N.E. $265,266(1917))$.

90. Justice Stewart wrote this of the statute in his dissent to Griswold v. Connecticut, 381 U.S. 479,527 (1965). 
clumsily, obliquely, and interstitially. Statutes of the kind challenged in privacy cases may often be understood as attempting to influence behavior indirectly, by reinforcing in people attitudes that encourage restraint in family and sexual settings. They may seek to induce what we might, loosely and perhaps hyperbollically, call "ascetic" attitudes toward family and sexual life. Let us call this, loosely and perhaps hyperbollically, the "socializing strategy."

The socializing strategy may be assessed in terms derived from the work of Stuart Hampshire. ${ }^{91}$ He observes that, while some systems of morality derive and acquire their unity from divine revelation or rational inquiry, morality can also derive and acquire its unity from a pattern of moral injunctions recognized in the experience, ideals, and practices of a group. This pattern of moral injunctions helps define a way of life, and that way of life helps give meaning to the life of the group and the lives of its members. Systems of morality of this kind, as Hampshire argues, typically include:

\begin{abstract}
a number of different moral prohibitions, apparent barriers to action, which a man acknowledges and which he thinks of as more or less insurmountable, except in abnormal, painful and improbable circumstances. One expects to meet these prohibitions, barriers to action, in certain quite distinct and clearly marked areas of action; these are the taking of human life, sexual relations, family duties and obligations, and the administration of justice according to the laws and customs of a given society. In the face of the doing of something that must not be done, and that is categorically excluded and forbidden morally, the fear that one may feel is fear of human nature. A relapse into a state of nature seems a real possibility or perhaps seems actually to have occurred . . . 92
\end{abstract}

In Hampshire's understanding, then, society is defined (in one significant but not exclusive way) by a series of emphatic moral prohibitions about the family, sexual relations, and violence. These prohibitions, while not necessarily related to each other in a purely logical sense, are related in people's minds through similarities in subject matter and through their integration into a way of life. The statutes challenged in privacy cases conspiciously deal with precisely those subjects, and on this view, they may be attempts to influence behavior by affirming those strategic moral prohibitions.

Understanding this larger purpose suggests a problem with much stateinterest analysis. Courts examine each statute in isolation, asking only how important its particular prohibition is and whether the statute effectuates that prohibition. But the importance of the prohibition depends in part on the importance of the larger socializing scheme. That scheme includes the whole set of statutes and the whole set of social practices and institutions that conduce to socialization in familial and sexual restraint. And a statute may be critical to that scheme without being intrinsically important.

The argument here is not that the statutes we are considering serve a state interest in preserving some system of morality, either for its own sake or because it is widely valued by the members of a society, although such an

91. I am drawing here on S. Hampshire, Morality and Conflict (1983), particularly Chapter 4, Morality and Pessimism.

92. Id. at $87-89$. 
argument could be made. ${ }^{93}$ Rather, the argument is that, by reinforcing a constraining system of morality, these statutes may serve two state interests, one clearly legitimate and one possibly legitimate. ${ }^{94}$ First, these statutes may help deter destructive behavior within families and regarding sexual behavior. They may, that is, help deter behavior that is specifically and uncontroversially criminal but hard to prevent and hard to heal-most significantly, rape, child abuse, and spouse abuse. They may also help deter legal but deleterious behavior-the injuries to spouses and children often associated with divorce are an example.

The second, more problematic, justification of these statutes is that they may inhibit the growth of what might be called an offensive social environment. This justification assumes (controversially) that there is a legitimate state interest in resisting such an environment. This assumption finds its authority in law in Paris Adult Theatre I. v. Slaton, ${ }^{95}$ in which the Court held "that there are legitimate state interests at stake in stemming the tide of commercialized obscenity .... [The rights and interests involved] include the interest of the public in the quality of life and the total community environment ..."96 The ordinary response to this justification, of course, is that the prevention of offense cannot justify a statute that infringes any significant personal interest, since offense is a relatively slight injury and since, to avoid being offended, one need only turn one's head. Nevertheless, the offensive-environment argument should not be rejected out of hand. For in this respect, too, statutes ought not to be treated in isolation. A certain amount of offense must undoubtedly be socially tolerated, if only because of the enforcement problem. But, while any single offense, and even any particular kind of offense, may be tolerable, some kinds of offense may be cumulatively intolerable. Furthermore, offense may domesticate itself, creating a slippery slope-as we become accustomed to one kind of offense, the next kind comes to seem more tolerable. Eventually, we find ourselves tolerating what ought to be intolerable. ${ }^{97}$

93. The Court has not decided whether preserving a system of morals is a compelling state interest, and one might suppose that the Court's failure to adduce that argument in, for example, Roe $v$. Wade implies that that argument would fail. In Bowers v. Hardwick, however, the Court, after deciding that no fundamental rights were at stake, considered the rational-basis argument that the state's sodomy statute was justified only (and thus inadequately) by "the presumed belief of a majority of the electorate in Georgia that homosexual sodomy is immoral and unacceptable." 478 U.S. at 196 (1986). The Court denied that this belief provided an insufficient basis for the law: "The law ... is constantly based on notions of morality, and if all laws representing essentially moral choices are to be invalidated under the Due Process Clause, the courts will be very busy indeed." Id.

94. Let us put aside the unresolvable question of whether they are "compelling" interests.

95. 413 U.S. 49 (1973).

96. Id. at $57-58$.

97. For a thoughtful discussion of this point, see G. Calabresi, Ideals, Beliefs, Attitudes, And the law: Private Law Perspectives on a Public law Problem 69-86 (1985). See also Schneider, supra note 3 , at part $\mathrm{V}$. 


\section{The Socializing Strategy and the Constitutionalization} OF SOCIAL ISSUES

\section{A. Assessing the Socializing Strategy: The Pessimistic View of Human Nature}

I have been intimating that if we look at some criticisms of ordinary stateinterest analysis, we can discern in the socializing strategy the shape of a broader view of the permissible scope of the state's interest in legislation subject to a privacy-rights attack. But is that view at all convincing? Do these statutes socialize? Will people behave badly if not nurtured in a culture of constraint, or is it the culture of constraint itself that nurtures bad behavior? Will a culture of constraint improve behavior enough to justify its undoubted costs? Will a set of specific statutes of the kind we are discussing contribute significantly to a culture of constraint?

These questions are all, I suppose, empirical questions. But they are empirical questions which we cannot answer now and which we are unlikely to answer soon. Little of the necessary empirical work has been done; 98 nor is it likely to be illuminating when it is done: The empirical evidence will differ from place to place and time to time. It is absurdly difficult to design studies that measure the effects even of direct penalties for specific behavior, as the history of research on deterrence shows. It would be yet more difficult to isolate and test the effects on a whole category of behavior of a whole system of legal and social regulation. These and many other problems with conducting empirical research must cripple attempts to evaluate the soundness of the socializing strategy. Because we lack empirical evidence we must fall back on assumptions and principles. We are driven, that is, to confront a problem crucial to many family law issues but rarely discussed directly-the question of what human nature is. When questions about the

98. As Professor Melton comments,

One of the most curious remaining gaps has been in the effect of law on behavior. This general topic should be a natural for psycholegal study, in that perhaps the most obvious and pervasive psychological assumption in the law is that the law is effective in controlling behavior. . . However, social scientists, especially psychologists, have given very little attention to the significance of law in everyday experience and behavior.

Melton, Introduction: The Law and Motivation, in The LAw as a Behavioral. Instrument at xiii (G. Melton ed. 1986). Professor Melton notes that research has been especially scanty in an area that particularly interests us: "[T]he most important effects of law may be symbolic, and social scientists have been late to recognize the functions of the law that are not directly instrumental or utilitarian." $I d$. at xvii (emphasis in original). There are occasional hints in the literature that the law can influence social behavior even where fear of punishment is slight. Professor Bonnie reports, for instance, that "mandatory seat-belt laws represent a convincing illustration of the declarative effect of a legal prohibition. ... We know that $40 \%$ of the driving population who did not wear seat belts before [a law requiring seat-belt use] was passed, and were not persuaded by educational efforts, began to do so in immediate response to the law." Bonnie, The Efficacy of Law as a Paternalistic Instrument, in The Law as a Behavioral Instrument 131, 185 (G. Melton ed. 1986) (emphasis in original). For a sympathetic account of the law as an instrument of socialization and social structure, see Melton \& Saks, The Law as an Instrument of Socialization and Social Structure, in THE LAW AS A Behavioral Instrument 235 (G. Melton ed. 1986). 
socializing strategy are seen in that light, they begin to seem less exclusively empirical. They begin, rather, to implicate life's imponderables.

How should a court respond to legislation that rests on a view of human nature which, like all such basic views, is not in any useful sense susceptible of proof? This question-which is in some ways subsidiary to the general problem of legislating in circumstances of empirical uncertainty-can be approached in many different ways. The Court addressed the question most relevantly to our purposes in an obscenity case, Paris Adult Theatre I. $v$. Slaton:

It is not for us to resolve empirical uncertainties underlying state legislation, save in the exceptional case where that legislation plainly impinges upon rights protected by the Constitution itself . . Although there is no conclusive proof of a connection between antisocial behavior and obscene material, the legislature of Georgia could quite reasonably determine that such a connection does or might exist. In deciding Roth, this Court implicitly accepted that a legislature could legitimately act on such a conclusion to protect "the social interest in order and morality" . . . .99

How aptly this quotation fits our cases and what consequences it should have for them are not fully clear. However, two standard arguments about the role of courts speak to their capacity to review statutes that rest on legislative conclusions about human nature: first, that courts are less suited than legislatures to acquire and assess evidence about legislative facts; second, that in a democracy, legislatures speak with more authority than courts because legislatures are intended to represent the people and courts are not. In the ordinary case, these two arguments yield a strong presumption that a statute is adequately founded in empirical reality and social theory; in any case they merit respect, particularly where the state's interests are pressing yet difficult to serve. However, the cases we are discussing here involve privacy rights which are arguably of special constitutional importance and which thus may arguably not be infringed on the basis of insubstantial theories. Therefore, it may be reasonable to say that, when deciding whether to impinge on a fundamental privacy right, a legislature may not be judicially prevented from consulting a theory like a theory of human nature at least where the theory has been substantially relied on in the past and where it has substantial intellectual antecedents. ${ }^{100}$

99. 413 U.S. 49, 60-61 (1973) (quoting Roth v. United States, 354 U.S. 476, 485 (1956)) (emphasis in original). The Court spoke to a somewhat different aspect of this issue in Carey v. Population Services Int'1, 431 U.S. 678, 695 (1977), where it noted the absence of evidence that the statute served the state's purpose and the presence of evidence that it did not. Then, however, the Court announced that "the studies cited by appellees play no part in our decision. It is enough that we again confirm the principle that when a State, as here, burdens the exercise of a fundamental right, its attempt to justify that burden as a rational means for the accomplishment of some significant state policy requires more than a bare assertion, based on a conceded complete absence of supporting evidence, that the burden is connected to such a policy." Id. at 696 .

100. In ascertaining whether there is a fundamental right of some kind, the Court has long consulted historical practice. The standard I propose here may be seen as applying that same principle to the state-interest issue. As Justice Harlan wrote,

The best that can be said is that through the course of this Court's decisions [substantive due process] has represented the balance which our Nation, built upon postulates of respect for the liberty of the individual, has struck between that liberty and the demands of organized society. ... The balance of which I speak is the balance struck by this country, having regard to 
Before we apply this test to our present problem, let me make two comments. First, we should recall that all schemes of statutory regulation are ultimately based on unprovable assumptions about human nature. Given this fact, given the significance of many of the social goals which can be at stake in privacy litigation, and given the desirability of permitting new ideas about human nature to become the basis for legislation and of allowing citizens in a democracy to legislate on the basis of their deepest beliefs about human nature, I believe that the test I have proposed is; if anything, too restrictive. However, I use it here because I think it provides the hardest reasonable test for the pessimistic view. My second comment is to emphasize that I will be discussing the proper scope of judicial review, not the preferable course of social policy. Thus, the discussion which follows asks whether a legislature may rely on a particular view of human nature, not whether a legislature should do so.

The view of human nature on which these statutes seem to rely I will callfor want of a better term-the pessimistic view. Let me now define it somewhat more fully, if abstractly and ahistorically. The pessimistic view is not the product of any one tradition, but appears in various forms in many traditions. It may see man's nature as evil; it at least believes man is easily led to harm himself and other people by his own self-interestedness. The pessimistic view is not necessarily hostile to the pleasures of the senses, though it can be. ${ }^{101}$ It does, however, appreciate the power of those pleasures and recognizes that they can divert men from better ends and drive men toward worse ones. It therefore contrives to channel those pleasures into the service of good, as when it summons sexual passion to exalt love in marriage. Insofar as man's distracting or destructive propensities cannot be channelled into good, this view of human nature hopes to curb those propensities by social conditioning which seeks to internalize self-restraint.

The pessimistic view of human nature-although crudely sketched heremeets the two criteria I have proposed courts should use in reviewing legislation that rests on empirically unprovable theories. First, it sails past the historical-practice test. It is, to begin with, consonant with the attitude that informed the relevant texts of the Constitution itself. As Rogers Smith writes,

The liberalism of the Framers ... did not view the end of the state as the equal protection of the right of each to think and do as he wished. Early liberals . . were confident that they could identify the activities and beliefs reason permitted and sometimes required, and that they could then draw lines distinguishing "liberty," which encompassed such rational activities and beliefs, from "license," the expressions of man's baser desires and passions.

what history teaches are the traditions from which it developed as well as the traditions from which it broke.

Poe v. Ullman, 367 U.S. 497, 542 (1961) (Harlan, J., dissenting).

101. For arguments that Puritanism, American Christianity, and Victorianism were less hostile to those pleasures than is conventionally assumed, see, respectively, E. Leires, The Puritan Conscience and Modern Sexuality (1986); P. Gardella, Innocent Ecstasy: How Christianity Gave America an Ethic of Sexual Pleasure (1985); P. Gay, Education of the Senses (1984). 
The claim that true liberty requires the rule of reason over the passions was a chief characteristic of the "moderate Enlightenment" liberalism embodied in the Constitution ....

. [U]ltimately, for the liberal intellectuals at least, the pleasures of the mind, the delights of wisdom and moral virtue, were still seen as higher than those of the body, and it was such rational perfection that men should seek most of all. ${ }^{102}$

In addition, the pessimistic view of human nature was historically a commonplace basis in America for law specifically and the regulation of social behavior generally. Such a view of human nature expressly underlay the colonial approach to family law and implicitly undergirded family law throughout the nineteenth century. Late eighteenth-century law (the law of the Constitution's era) regulated the family intensively and intrusively and embodied precisely many of the prohibitions now challenged on privacy grounds, including the prohibitions of fornication, cohabitation, adultery, abortion, ${ }^{103}$ sodomy, and incest, to say nothing of the virtual prohibition of divorce. Late nineteenth-century law (the law of the fourteenth amendment's era) preserved those prohibitions and added new ones, including the Comstock laws (regulating contraceptives), whose invalidation has been so central in the development of the privacy doctrine. In sum, because the pessimistic view has been the dominant view at least through most of our history and has been effectively attacked as a basis for legislation only in recent decades, the historical-credentials test is safely met. ${ }^{104}$

The intellectual-credentials test is perhaps more problematic than the historical-antecedents test, because the pessimistic view of human nature has gradually lost the allegiance of many modern intellectuals. Nevertheless, that view is so much a part of three powerful intellectual traditions that the second test is satisfied as well.

The first of these traditions is Christianity. ${ }^{105}$ Rich and robust currents in both Catholicism and Protestantism have held that man is naturally sinful, that sin particularly manifests itself in family and sexual life, and that this human tendency must be constrained through an elaborate system of inhibitions, proscriptions, and renunciations. Although those currents may have flowed most profusely from St. Augustine and John Calvin, they flow freely even today. ${ }^{106}$ And while the Christian version of this understanding of human nature has been the one most influential in American history, its ascetic

102. Smith, The Constitution and Autonomy, 60 TEx. L. Rev. 175, 177-78 (1982) (footnotes omitted).

103. Schneider, Moral Discourse and the Transformation of American Family Law, 83 Mich. L. Rev. 1803, 1869 (1985).

104. See generally Schneider, supra note 103.

105. I am not, of course, arguing here that it is legitimate to enact specifically religious doctrine into law. Rather, I am arguing that the pessimistic view of human nature can less readily be dismissed by a court if it has been taken seriously by any of the strong, mainstream intellectual traditions in American life, of which Christianity is surely one. In thinking about the extent to which ideas with religious roots may be used in making policy, I have benefitted from Greenawalt, Religious Convictions and Lawmaking, $84 \mathrm{MICH}$. L. Rev. 352 (1985). I commend that article to the reader, although I do not subscribe to all its arguments.

106. See S. Lyman, The Seven Deadly Sins: Society and Evil 53-86 (1978). 
aspects find their equivalents in many of the world's major religions and in significant aspects of classical philosophy.

The second tradition supplying intellectual weight to the pessimistic view of human nature is psychology. Psychology is obviously a two-edged sword, because it is also a leading contributor to the opposite and now potent view of human nature and to a corresponding view of social policy that calls for relaxing social constraints. Yet for just this reason we need to recall psychology's darker strain. Men, Freud tells us in a chilling passage from Civilization and its Discontents,

\begin{abstract}
are not gentle creatures who want to be loved ...; they are, on the contrary, creatures among whose instinctual endowments is to be reckoned a powerful share of aggressiveness. As a result, their neighbour is for them not only a potential helper or sexual object, but also someone who tempts them to satisfy their aggressiveness on him ..., to use him sexually without his consent ..., to humiliate him ..., to torture and to kill him. Homo homini lupus. [Man to man is a wolf.]

Civilization [therefore] has to use its utmost efforts in order to set limits to man's aggressive instincts and to hold the manifestations of them in check by psychical reaction-formation. ${ }^{107}$
\end{abstract}

The third of the traditions is sociology. As Professor Grey observes, "[E]very thinker of the great central tradition of the last century's social thought has seen repressed sexuality and the authoritarian family structure as close to the core of our civilization. Conservative theorists have defended repression as necessary; revolutionaries have urged that society would have to be overthrown to free us from its tyranny." 108 A classic statement of this view is, of course, Max Weber's The Protestant Ethic and the Spirit of Capitalism, which attributes the rise of the capitalist ethos to an unquenchable religious asceticism:

Combined with the harsh doctrines of the absolute transcendality of God and the corruption of everything pertaining to the flesh, this inner isolation of the individual [caused by turmoil induced by the doctrine of predestination] contains . . . the reason for the entirely negative attitude of Puritanism to all the sensuous and emotional elements in culture and in religion, because they are of no use toward salvation 109

As capitalism developed, some of the religious elements of that asceticism faded, but there remained a "rational asceticism" which condemned impulsive enjoyment of life as leading "away both from work in a calling and from religion." 10 More generally, sociologists have been absorbed by the problem of how society constrains and channels the disruptive force of

107. S. Freud, Civilization and its Discontents 58-59 (1930). See generally P. Rieff, Freud: The Mind of the Moralist (1959); P. Rieff, The Triumph of the Therapeutic (1966). For an intriguing criticism of modern psychology and psychiatry for being "more hostile to the inhibitory messages of traditional religious moralizing than is scientifically justified," see Campbell, On the Conficts Between Biological and Social Ezolution and Between Psychology and Moral Tradition, 1975 AM. Psychologist 1103, 1103.

108. Grey, supra note 45 , at 92 .

109. M. Weber, The Protestant Ethic and the Spirit of Capitalism 105 (T. Parsons trans. 1958).

110 . Id. at 167. 
passion."11 Indeed, Stanford Lyman argues that the social sciences themselves have "sought to control lust by splitting its facets into those that seemed worthy of support, such as love, rationality, affection, companionship, and those that crippled the social order, such as romantic illusions, erotic escapades, and sexual practices deemed deviant." 112

As these brief allusions suggest, then, the pessimistic view of human nature and a reliance on systems for internalizing control of human behavior (particularly in family and sexual life) have roots that range deep and wide in our national experience and in Western thought. What is more, the pessimistic view still has many adherents, even if they are now less influential than they once were. And faith in these socializing techniques persists today: both sides of the political spectrum advocate them in practice, if not in principle. The right's faith in them is well known; the left's is less acknowledged, but is apparent in, for instance, feminist arguments for regulating pornography ${ }^{13}$ and curbing spouse abuse and in liberal arguments for governmentally attacking racial and gender attitudes and stereotypes. Nor is the choice between the pessimistic view and its opposite necessarily a choice between social control and no social control. On the contrary, many social critics describe a new set of ideals and institutions which speak the softer language of therapy but which constrain as firmly as the old ideals and institutions. ${ }^{114}$

111. See S. Lyman, supra note 106, at 87-102; Goode, The Theoretical Importance of Love, 24 Am. Soc. REV. 38 (1959).

112. S. Lyman, supra note 106 , at 108 .

Professor Grey has a more extended yet still concise description of the pessimistic view (or at least of the particularly sexual aspects of the view), which he describes as "a view that has been central to modern thought and far more widely accepted in our time than contemporary versions of the liberalism of John Stuart Mill." Grey, supra note 45, at 83, 91. Professor Grey points out as well that "the Marxist enemies of bourgeois society have preached a similar message from a different perspective." Id. at 94 . Indeed, he goes further than I would be willing to in saying that there are few spokesmen for the contrary view (which, in his understanding, "would ascribe to sexuality a considerable importance in the lives of individuals ... and . . would hold that the way sexual relations are carried on, at least among consenting adults, has no great effect on the welfare of society outside the sexual sphere." Id. at 94). He puts Bertrand Russell squarely in this camp, finds "something of the same spirit" in Michel Foucault, and concludes by adding Norman O. Brown to the list. Professor Grey may be right that this view has few spokesmen, although I doubt they are as few as he seems to suggest. See, e.g., P. Robinson, The Modernization of Sex (1976). In any event, the opposite of the pessimistic view should, I suppose, be the optimistic view. It would hold, essentially, that human nature is basically benign and that social constraint and social injustice are what cause harmful behavior, or at least inhibit good behavior. That view is widely popular in society generally. (For a description of this attitude's American roots, see Lears, From Salvation to SelfRealization: Advertising and the Therapentic Roots of the Consumer Culture, 1880-1930, in The Culture of Consumption: Critical Essays in American History, 1880-1980, at 1 (R. Fox \& T. Lears eds. 1983)). That view may be prepotent in American family law. See Schneider, supra note 103.

113. See Brest \& Vandenberg, Politics, Feminism, and the Constitution: The Anti-Pornography Movement in Minneapolis, 39 Stan. L. Rev. 607 (1987).

114. Among many examples is C. Lasch, Haven in a Heartless World (1977). See also de Swaan, The Politics of Agorphobia, 10 TheOry \& Soc'y 359 (1981). 


\section{B. Assessing the Socializing Strategy: The Political and Social Context}

At this point, one might concede the pessimistic view of human nature and the socializing strategy which acts on it, and yet insist that, at least as to "privacy" issues, such a strategy would not work in the United States today. The argument would be that a socializing strategy relies on some degree of social consensus and that any degree of consensus about family law issues has evaporated. The argument would continue that the socializing strategy relies on an understanding and acceptance of the ascetic view but that that understanding and acceptance are no longer common. There is surely much to that argument. How should a court considering a constitutional privacy challenge to a "socializing" statute deal with it? This is not the place for a full-dress review of that question, for it raises an elaborate set of empirical problems. I will, however, make three observations about the present American situation and then draw a conclusion from them.

First, I suspect that our idea of the extent and permanence of dissensus generally, and of dissent from the ascetic view particularly, is skewed by the unexamined assumption that change in social behavior (particularly change in family law matters) is unidirectional - that change will always liberalize social rules. Historically, however, this has not been true. For instance, constraints on family and sexual behavior tightened markedly between the Elizabethan sixteenth century and the Puritan seventeenth century and between the Regency eighteenth century and the Victorian nineteenth century. ${ }^{115}$ As those two examples suggest, social change is not unidirectional for two significant reasons. First, its causes are too various and numerous for social change to proceed uniformly, as the sudden appearance of AIDS and the social response to it ought to remind us. Second, social change of this kind is not uncontrollable; it is in part produced by manipulation of social policy. Throughout history groups have reacted, sometimes quite successfully, against what they perceived as inadequately constrained social behavior. Such reactions are in fact occurring today, and not just among the religious right.

In any event, as a matter of social policy, it ought to be possible deliberately to adjust social rules as their effects become evident. We have, for example, just undergone a transformative change in family life and attitudes. Not all those changes have been beneficial, and attempts to reverse or moderate harmful changes ought not be foreclosed by a falsely teleological sense of social development.

My first observation, then, is that the direction of change is not inevitably toward liberalized rules and thus that the socialization strategy is not necessarily a doomed rear-guard action. My second observation is that despite the many forces that impel the United States as a whole toward dissensus, there are probably still states and even regions in which traditional

115. See generally L. Stone, The Family, Sex and Marriage in England 1500-1800 (1977). 
social norms are widely accepted. 16 Some regions, notably the South, have maintained a degree of cultural distinctiveness as to family law issues, a distinctiveness in part sustained by differences in religious affiliation and other cultural traditions. Differences are even more pronounced between states than between regions, of course, partly because these differences are sustained by substantial differences in another important factor shaping attitudes on those issues-the degree to which they are urban or rural. While few regions are without urbanized states, some states remain quite rural. And individual states are more susceptible than whole regions to the influence of cultural traditions. Indeed, in at least one state-Utah-religious affiliation has had a predominant effect in shaping the state's culture and its family law attitudes.

My third observation is one that has increasingly seemed significant to me. Opinions about many family law questions diverge significantly on class lines. Very roughly, elite elements of the upper-middle class tend toward liberal views; the lower-middle class tends toward conservative views. ${ }^{117}$ As Peter Skerry argues,

There is much evidence to suggest that abortion is part of a network of cultural issues-including gay rights, pornography, and sex education-that threatens to divide further the traditionally Democratic working and lower-middle classes from the reform wing of the party and perhaps from the mainstream of American politics. Abortion is part of a larger cultural conflict between certain strata of the upper-middle

116. For example, $57 \%$ of the Southern respondents but only $41 \%$ of the Western respondents favored "[a] ban on all abortions except in cases of rape, incest, or when the mother's life is endangered." Gallup Poll, Public Opinion 1984, at 240-41 (1985). Similarly, 48\% of the Southern respondents but only $24 \%$ of the Western respondents thought premarital sex was wrong. Gallup Poll, Public Opinion 1985, at 109-11 (1986). See generally, e.g., Abrahamson \& Carter, Tolerance, Urbanism, and Religion, 51 Am. Soc. REv. 287 (1986); Wilson, Urbanism and Tolerance: A Test of Some Hypotheses Drawn from Wirth and Stouffer, 50 AM. Soc. REv. 117 (1985); Stephan \& McMullin, Tolerance of Sexual Nonconformity: City Size as a Situational and Early Learning Determinant, 47 Am. Soc. Rev. 411 (1982); J. Reed, The Enduring South: Subcultural Persistence in Mass Society (1986).

117. It has become difficult to talk about class (or even to define the term) in post-industrial society, and it has always been difficult to talk about class in America. Thus, I cannot here deal in precise terms with whether the views I loosely attribute to elite elements of the upper-middle class are better attributed to the upper-middle class generally, to the "new class," to specific sub-classes of the middle class, to specific status groups, to specific occupational groupings, to educated elites, or what have you. It is, of course, hardly easier to define the group I loosely refer to as the lowermiddle class. The following works, however, provide both evidence of the general phenomenon I am describing and discussions of how it is best analyzed. For a general description of changes in American class structure, attitudes, and behavior, see J. Bensman \& A. Vidich, American Society: The Welfare State and Beyond (1987). That work attempts "to define and describe the emergence of a new America, an America dominated by a new middle class and its lifestyles." Id. at vii. For an analysis of some of the cultural consequences of that change, see D. Bell, The Cultural Contradictions of CApitalism (1978). For a series of essays variously suggesting, describing, and denying the emergence of the "new class" (loosely defined as an "educated elite"), see THE NEW CLAss? (B. Bruce-Briggs ed. 1979). For a helpful and recent effort to bring some analytic rigor to the reasons for the "rise of left-of-center political views in broad sections of the educated middle class [that] has been one of the distinctive-and one of the more surprising-features of postwar American politics," see Brint, "New-Class" and Cumulative Trend Explanations of the Liberal Political Attitudes of Professionals, 90 AM. J. Soc. 30, 30 (1984). For an extensive description of the differences in class view between elites and non-elites, see H. MCCloskey \& A. Brill, Dimensions of Tolerance: What americans Believe about Civil Liberties (1983), particularly chapter 5, The Rights of Privacy and Lifestyles. See also sources cited infra note 120. 
class-the highly educated professionals, scientists, and intellectuals-and the mass of Americans who comprise the working and lower-middle classes. ${ }^{118}$

These class differences are exacerbated by the fact that many of those who partake most strongly of the views I have described as lower-middle class are also distanced from elite culture by their membership in relatively recent immigrant groups and in lower-status religious groups. All this represents a remarkable historical shift. In the nineteenth and early twentieth centuries the upper-middle class is often thought to have imposed restrictive social rules on an unwilling lower-middle class (and particularly on ethnic groups); today the upper-middle class wants to escape those rules while the lowermiddle class (particularly, though far from exclusively, many of its ethnic components) wants to retain them. In sum, as in that earlier period, we see once again not only a dispute over the substance of the law and over the kind of community we are to be, but a dispute over the status of contending elements of American society. Now, however, the lower, and not the higher, status groups are the ones that seem to be struggling to sustain existing social rules. ${ }^{119}$

This broad cultural and political conflict is intensified, I believe, by an attitude that has always been present, but which we may have allowed ourselves to forget. It is the feeling that reason is the best guide to policy, that the educated-particularly professionals like lawyers-are better equipped to reason than the less educated, and that the educated are therefore better equipped and better entitled to govern. This feeling finds its institutional expression in a preference for extending the authority of courts, the branch of government to which the elite has the easiest and in many ways the most exclusive access. This feeling has, I believe, been intensified by several issues-particularly issues involving race, crime, and religion-about which there have been marked class differences and about which the elite has been especially certain of its rectitude. These issues have reinforced in many of the elite the sense that the majority is likely to be corrupt and tyrannical and the political process to be unrepresentative and that this necessitates a vanguard of the majority which will rule in the majority's stead and better interests and in the interests of all minorities. I have been struck at how often I observed these attitudes in one place of present privilege and future power-among my former classmates and my current students, a startling number of whom believe that their education (especially their legal education), their intellectual ability, and their freedom from prejudice and from the superstition of religion give them a superior moral claim to political power. Such beliefs contribute to and are reinforced by their passionate

118. Skerry, The Class Conflict over Abortion, The Pub. Interest, Summer 1978, at 69, 70.

119. Cf. J. Gusfield, Symbolic Crusade: Status Politics and the American Temperance Movement (1963). I am not adopting Gusfield's argument that status discontent has caused the social attitudes described here. Insofar as I am making a causal argument, it is that differences over social issues have been exacerbated by class antagonisms. See Wood \& Hughes, The Moral Basis of Moral Reform: Status Discontent is. Culture and Socialization as Explanations of Anti-Pornography Social Movement Adherence, 49 Aм. Soc. Rev. 86 (1984). 
commitment to a conception of judicial review which emphasizes the failings of democratic processes and majorities and the superior enlightenment of judges. The lower-middle class has, partly in response, come to feel disvalued and even despised. Its relative lack of education, its relative depth of religious belief, and its mistaken and improper social views, it has been made to understand, evidence its relative unfitness to participate in government. ${ }^{120}$

I believe that a deplorable consequence of the constitutionalization of family law has been to increase the confidence of the elite and the bitterness of the rest. It has increased the confidence of the elite to discover once more an issue about which the democratic branches of government have proved irresponsible. It has increased the bitterness of the rest to learn that their views on social policy are once again not just vanquished, and not just wrong, but constitutionally illegitimate. ${ }^{121}$ In short, a socially destructive situation has arisen whose consequences need at least to be considered in thinking about the constitutionalization of social issues generally and vice issues particularly.

\section{The Constitutionalization of Social Issues: Conflict and Compromise}

I would conclude from these three observations that, if social dissensus about family law issues is not inevitable, and if a particular state has something like social consensus as to them, ${ }^{122}$ that state's legislature ought to be constitutionally able to make the socialization policy one of its interests. Acknowledging that policy as a legitimate interest might promote a goal we

120. Let me give an anecdotal illustration of the attitudes that give rise to this feeling. I recently received (at my office and my home) what purported to be an "official document" from the ACLU which was intended to persuade me to urge that former Attorney General Meese be removed from office. I do not admire the former Attorney General, but I detest this sentence from the ACLU's cover letter: "[I]t is only a very small and special group of Americans (less than 1\%) who understand the importance of fighting to sustain individual freedom ...." For scholarly examinations of the attitudes that underlie such arrogance and of the lower-middle-class reaction to it, see Hochschild, Dimensions of Liberal Self-Satisfaction: Civil Liberties, Liberal Theory, and Elite-Mass Differences, 96 ETHICs 386 (1986); Smith, Book Review, 72 Cal.if. L. Rev. 908 (1984) (reviewing H. McCloskey \& A. Brill, supra note 117); J. Rieder, Canarsie: The Jews and Italians of Brooklyn Against liberalism (1985); K. Luker, Abortion and the Politics of Motherhood (1984); B. Berger \& P. Berger, The War Over the Family (1984); R. Neuhaus, The Naked Public Square (1984); P. Clecak, America's Quest for the Ideal Self: Dissent and Fulfillment in the 60s and 70s, at 70-75, 125 44 (1983); Rodes, Greatness Thrust Upon Them: Class Biases in American Law, 28 AM. J. JuRISPRUdenCE 1 (1983); Skerry, supra note 118, at 69; Page \& Clelland, The Kanawha County Textbook Controversy: A Study of the Politics of Life Style Concern, 57 Soc. Forces 265 (1978). For a discussion of lawyers in this respect, see Glazer, Lawyers and the New Class, in The New Class? ch. 7 (B. Bruce-Briggs ed. 1979).

121. I am not, of course, suggesting that any time there are class differences over social issues, the Court is inhibited from finding legislative action unconstitutional. Where, as in the race situation, the Constitution speaks directly to an issue and there is an overriding moral imperative, these class considerations are much less pressing, although sensitivity to them is both tactically wise and ethically compelled.

122. Ordinarily, a statute need only be supported by a majority (as that term is applied in a representative democracy), and I am suggesting no change in that standard. I refer to consensus here because some significant level of social agreement, although hardly anything like unanimity, is necessary to make the socializing strategy work optimally. I suspect that the requirement of a consensus is, if anything, too strict, since a legislature may sometimes plausibly believe that a socializing strategy is worth employing as part of an attempt to build, and not just sustain, desirable social attitudes. 
discussed in the first half of this essay-helping courts assess state interests less rigidly, more complexly, and more fully. It might, in other words, increase the analytic flexibility and frankness so often lacking in fundamentalrights reasoning. But I wish here to emphasize an advantage of recognizing the socializing strategy that responds to some of the concerns I raised in part IV.B-that it would ease social compromise. Such compromise seems to me desirable in most areas of public policy in a democracy, and particularly so in matters as emotionally and morally freighted and perplexing as family law. That is, compromise is desirable where substantial numbers (and especially where substantial identifiable groups) of reasonable citizens differ on legitimate grounds as to matters about which they feel deeply and as to which losing (especially losing in a way which emphasizes the illegitimacy of their opinions) will deprive them of a sense-or worse, the reality-of participation in the polity.

But compromise is easy to want and hard to get. How can social disputes be structured to promote compromise? Courts are sometimes thought of as neutral arbiters and thus as good architects of compromise. However, the capacity of courts to achieve social compromise has significant limits. Some of these limits have to do with the structure of litigation. For instance, the adversary system, and the likelihood that a court's decision will proclaim a winner and loser, set initial limits. That cases come up one at a time means that all the issues that would need to be included in a compromise are unlikely to be judicially resolved simultaneously and that all the parties to a dispute are unlikely to be involved simultaneously. Indeed, in any complex social dispute, some parties are likely to be interested in some aspects of the dispute, but not in others. These factors make it unlikely that all the parties can be persuaded to come together and work out or accept a judicial compromise to which all would be committed. In politics, a compromise which commits the parties can expressly or implicitly be negotiated among them and because of that fact can often be informally enforced; in litigation, the parties may not realize that a compromise point has been reached, and in any event there is little to stop anyone, "party" or not, from bringing the next suit and thus disrupting the compromise. Yet other factors limit the capacity of courts to orchestrate social compromise. Because of the pressure to develop an internally consistent line of cases and because judicial legitimacy is generally thought to inhere in disciplined reasoning from principles, a court's ability to shape a compromise is much constrained. Further, since legal categories are often not the categories which matter to the parties, even if a court wishes to and legitimately may construct a compromise, it may be unable to evaluate accurately the scope and intensity of the parties' preferences. Finally, to phrase a dispute in terms of rights, particularly constitutional rights, inhibits compromise by raising the moral and social stakes that appear to be at risk. ${ }^{123}$

123. See Schneider, supra note 3, at part V. C. 
More specifically, social compromise is impeded by present fundamentalrights state-interest analysis. By now, at least, when the Supreme Court addresses family law problems, it is often not perceived as a neutral arbiter. Rather, it is perceived in many quarters as parti pris, as speaking outside of its proper authority and in the interests of its own professional and class perspectives. In addition, any desire the Court might have to construct a compromise is hobbled by its reluctance to acknowledge that any state interest can override a fundamental right and by the rigidity and artificiality that reluctance imparts to privacy jurisprudence. Finally, the best compromise is often one that dampens controversy before it becomes untamable. Yet constitutional litigation, by providing a well-publicized national forum for dispute and by offering a means of securing quick, national, and presumably final changes in the law, often sparks rather than dampens controversy.

This is not to say that compromise is impossible in the present system of privacy law. The entire body of privacy-rights law can be seen as an attempted compromise in which Bowers $v$. Hardwick (which held that prohibitions of homosexual sodomy are constitutional) balances Roe $v$. Wade and its progeny. But such a compromise is hardly likely to work. Partly this is for the reasons described above. For example, because Roe and Bowers arose seriatim and not simultaneously, Roe provoked an opposition which by the time of Bowers had defined itself in terms to which Bowers was in important ways irrelevant. Further, the social groups interested in the two cases are not identical. Nor can they be assured that the two cases represent a stable compromise, since they cannot know when someone will bring another suit which might alter the status quo.

Moreover, Bowers itself illustrates the awkwardness of compromise under the present system of privacy law. First, the case provokes serious doctrinal confusions, since most commentators and many courts not unreasonably thought that the privacy cases created a broad Millian privacy right which comfortably encompassed freedom in sexual matters between consenting adults. ${ }^{124}$ Such doctrinal perplexities typify the problems presented when compromise is attempted within a doctrinal area which the Court must attempt to treat as coherent. Second, the compromise of Bowers is in some ways especially troublesome, since the burden on homosexuals seems particularly onerous and since the state interest seems particularly problematic.

Of course, other forms of compromise are possible within the present system. In the abortion context, for example, the Court might after Roe have allowed the states to regulate abortion in many of the peripheral ways they have attempted in response to Roe. Indeed, the Court seemed briefly to be

124. For evidence of this view and for an argument that the view was, in practice if not logic, unwarranted, see Grey, supra note 45 , at 83 . 
doing just that in the abortion-funding cases. ${ }^{125}$ However, as the body of post-Roe abortion cases reveals, such compromise is cramped by the pressure to develop a consistent definition of the privacy right and by the weakness of state-interest analysis. ${ }^{126}$

In sum, although the present form of fourteenth amendment privacy law does not foreclose compromise, its rigidity and artificiality (and the nature of adjudication) inhibit it. I suggest that one consequence of a more accommodating state-interest analysis would be that compromise could be achieved, and achieved more easily, through federalism. In other words, under such an analysis, states which wished to legislate in sensitive areas could more readily do so; those states which did not wish to do so would not have to. This local-choice policy would help remove several unduly divisive issues-abortion is an obvious example-from national politics. It would allow citizens who felt strongly about family law issues to affect their state's law without imposing on states whose citizens felt differently. The localchoice policy could also help to soften the class hostility I described earlier by reducing the frequency with which the lower-middle class's views are ruled constitutionally unacceptable (without, of course, relieving that class of the obligation to fight politically for its policies).

Abortion provides a test case for much I have said here about social conflict and social compromise. In 1959, the ALI's Model Penal Code proposed a liberalized abortion law. In the early 1960's, an abortion-reform movement, propelled by a host of powerful forces and establishment organizations, rapidly gathered momentum. Between 1967 and 1971, seventeen states, including California and New York, reformed their abortion laws. California's new statute was moderate in tone but made abortion readily available; New York's instituted a scheme quite close to that eventually enacted in Roe. The legislative debates, as I remember them, were exemplary-earnest essays in morals and politics. It was at this point that the Court intervened with Roe $v$. Wade.

Had the Court not acted, I suppose the political process would have continued to deal with abortion. A number of states, particularly Northern and coastal states, would have adopted reforms which, in intent or in result,

125. Beal v. Doe, 432 U.S. 438 (1977); Maher v. Roe, 432 U.S. 464 (1977); Harris v. McRae, 448 U.S. 297 (1980). On abortion funding as an area of compromise, and for an illuminating discussion of compromise in abortion policy, see Sher, Subsidized Abortion: Moral Rights and Moral Compromise, 10 Phil. \& Pub. Aff. 361 (1981). For an argument that, rather than simply deciding cases and thereby annointing winners and casting out losers, "[ $t$ ]he substance of the Court's actions must be guided by the same principle as its form: to provoke and to redefine disputes that might lead contending parties toward mutual accommodation ...." see Burt, The Constitution of the Family, 1979 SuP. CT. REv. 329, 393. For a thoughtful discussion of some legal techniques for achieving social compromise, one including a treatment of compromise over abortion, see G. CaLABREsI, supra note 97, at 87-114. See also G. Calabresi \& P. Bobbitt, Tragic Choices (1978). For a valuable consideration of compromise in contemporary abortion law, see Kaplan, Abortion as a Vice Crime: A "What If" Story, Law \& Contemp. Probs., Winter 1988, at 151.

126. See, e.g., Akron v. Akron Center for Reproductive Health, 462 U.S. 416 (1983); Thornburgh v. American College of Obstetricians \& Gynecologists, 476 U.S. 747 (1986). See also my discussion at notes $26-35$, supra. 
would have made abortion virtually as available as it is today. A number of other states, particularly Southern and Western states, would not have done so. Neither pro- nor anti-abortion groups would have been entirely happy. But parties to a compromise rarely are, and both sides would have had much to be satisfied with. Abortions would have been available to anyone able to travel and to pay for the abortion. (Recall that even today many states do not pay for abortions for the poor and there is evidence that private philanthropy has done so instead.) Yet where anti-abortion feelings were strongest, the state would have expressed them. And because abortion would not have been given the national forum and the national publicity which Roe provided, a divisive and distorting influence would probably have been kept out of national politics.

The usual response to suggestions about social compromise in this area is that those who favor relatively restrictive family law rules should not be allowed to impose their views on other people, whatever state they live in. Part of the answer to that, of course, is that they may do so where the statute they use to do it has a sufficiently strong state interest. As I argued in part III, the socialization argument attempts to show how such rules may constrain harmful behavior and thus meet the state-interest test. But another part of the answer is that someone's views are inescapably going to be imposed on everyone else. As Professor Hochschild argues,

The very insistence that all viewpoints and most actions must be tolerated necessarily elevates one set of values above all others. There is no way around that conundrum; tolerance of all values requires that one value (tolerance) dominate all others. To some, this point is merely a clever ploy in a parlor game .... But to others, this point is a serious problem; their values or their definition of freedom (whether class revolution, fundamental Protestantism, or vegetarianism) are necessarily denied in a tolerant society .... [T] The question of the inhibitions required by tolerance is particularly problematic when the tension between civil liberties and other values parallels the split between elites and masses. When elites hold the values that epitomize liberalism, at least in the eyes of other elites, there is little opportunity for the mass public even to express, never mind institute, coherent and powerful alternatives. 127

Society necessarily is a system for producing ways of living, for constructing social reality and social meaning. Governmental institutions are unavoidably part of that process, and the Court often is urged by its admirers to be. Governmental institutions in fact have a particularly important role in the process, in part because they alone are expected to speak for society as a whole. I would not suggest that government neutrality and social tolerance are meaningless ideas, but for the reasons Professor Hochschild suggests, they often are unattainable in some important contexts. They are often unattainable when government helps construct social reality, for someone's view of reality must prevail. They are often unattainable when contending social groups feel they must struggle to preserve a way of life which they wish to lead and in which they wish to raise their children.

127. Hochschild, supra note 120 , at 398 . 
There is much to be said for the elite's argument that its positions are the tolerant ones. But given the difficulties of locating genuinely tolerant ground, courts, as nonmajoritarian and elite governmental institutions, need at least to be sensitive to the fact that the elite's tolerant positions and its substantive positions conspicuously tend to coincide. The "tolerant" positions on creationism in schools, sex education, pornography, divorce, sodomy, fornication, and cohabitation all reflect the elite's substantive preferences. ${ }^{128}$ Sensitivity is called for in part because it may alert courts to the times when the labels of tolerance and intolerance are being used inaccurately. Abortion provides an instance. It is often said that the anti-abortion position is intolerant and the pro-abortion position is tolerant (thus its advocates describe it as the "pro-choice" position). But if anti-abortionists are correct that fetuses are human beings, then criminalizing abortion is entirely within the range of the ordinary assumption that government has the power and even the duty to define and protect what it plausibly takes to be human life and that citizens may and should elect a government that will do so. Only by judicially imposing the view that fetuses are not human did Roe $v$. Wade make abortion a right and foreclose its opponents from exercising their otherwise commonplace power to act through the government to protect what they plausibly take to be human life. Yet, in no other area has the government been thought unauthorized to define "life." And when impositions of this kind are made by judicial constitutional decisions, they disturbingly state, at various levels of explicitness, that the losing side's views are illegitimate. ${ }^{129}$

128. Laws requiring motorcyclists to wear helmets may be an exception which proves the rule.

129. The opinion in Roe was particularly troubling on this score. As Dean Calabresi writes,

The Court, when it said that fetuses are not persons for purposes of due process, said to a large and politically active group: "Your metaphysics are not part of our constitution." This is far worse (and more dangerous) in a pluralistic society than the statement the Court sought 10 avoid making, namely, "Sorry, but your metaphysics are wrong. A fetus is not alive."

When ... the Court proclaimed that the truth of the beliefs did not matter . . . it immediately made that Constitution unacceptable to the holder of those beliefs. It said to highly defensive groups comprised in significant part of recent immigrants that their highest beliefs, their metaphysics, are not part of our law as represented by its most fundamental statement, the Constitution. ... It told them . . . that ... they could not be true Americans so long as they held to their beliefs. This was catastrophic because it reinforced doubts which the holders of antiabortion beliefs already had about their full acceptance in American society.

G. CAlabresi, supra note 97, at 95-96. Nor, with the possible exception of the abortion-funding cases, can the Court's later abortion opinions be called emollient. The Court has treated with suspicion the states' attempts to locate the highly uncertain line between permissible and impermissible abortion regulations, Thornburgh v. American College of Obstetricians \& Gynecologists, 476 U.S. 747 (1986), and has associated opponents of abortion with racists by harshly quoting Brown v. Board of Education, (" " $[\mathrm{I}] \mathrm{t}$ should go without saying that the vitality of these constitutional principles cannot be allowed to yield simply because of disagreement with them." " Thornburgh, 476 U.S. at 759 (quoting Brown v. Board of Educ., 349 U.S. 294,300 (1954)).

The legislative opposition to Roe, when viewed in the light of the differences between the post-Roe and the post-Brown cases, does not justify so haughty a judicial response. The Court in Brown, whatever that opinion's faults and whatever the ambiguities of the fourteenth amendment, was interpreting a constitutional text plainly directed at the problem of race. See Wechsler, Toward Neutral Principles of Constitutional Law, 73 HARv. L. Rev. 1 (1959). The Court in Roe, whatever the Lochner-era precedents, was interpreting a constitutional text which did not address explicitly, and which until shortly before had not been thought to address implicitly, the problem of privacy. The Court in Brown was unanimous; the Court in Roe was divided. The Court after Brown had become increasingly 
Sensitivity to the coincidence of the elite's tolerant and substantive positions is desirable for other reasons. For instance, insensitivity on this score exacerbates the problem of persuading the public that the government can act neutrally and is acting neutrally. That problem often arises when, for example, the government seeks to decriminalize behavior-fornication or the use of marijuana, for example-without suggesting a moral view of that behavior. People are less easily persuaded that the governmental action is neutral if they observe that neutrality seems to serve the substantive purposes of an identifiable group. Sensitivity to the coincidence of the elite's tolerant and substantive positions also may help courts realize that tolerance is sometimes perceived differently by different classes because of differences in their class experiences. Elites, for example, may be more tolerant of prostitution than the rest of society because they are less likely to encounter it involuntarily or to experience its environmental side effects. Such sensitivity may also help courts realize when to apply Professor Hochschild's warning that neutrality is sometimes impossible. This sensitivity is particularly needed at a time when the Court is widely called upon to be the great teacher of tolerance. Such sensitivity, then, should be part of a decision to constitutionalize a social issue and should inform judicial decisions once an area of law has been constitutionalized.

The social and political controversy over the privacy doctrine is in part a battle about modernity and modernization, for the views of the elite are very much those of modernity. In the United States, as throughout the world,

determined; the Court after Roe showed signs of doubts. The Court after Brown relied on and received crucial support from the political branches of government; the Court after Roe received relatively weak support from the political branches of government, and the President's appointment power was being used to reverse Roe. For all these reasons, then, there was greater cause to suppose that Roe more than Brown might be judicially limited and thus legitimately probed and even attacked through legislation and litigation.

In addition, the persistence of the legislative response to Roe has much to do with the Court's own failings. The Court, as we have seen, did not specify clearly what standard to use in examining the state interest in the post-Roe cases. Furthermore, many of the post-Roe cases have invalidated legislation on means, not purpose, grounds, thus seeming to suggest that a better drafted statute might be permissible. Indeed, much of the post-Roe legislation seemed directly responsive to hints in Roe and its sequelae, including the abortion-funding cases. In any event, resistance to novel constitutional doctrine is, within important limits, a legitimate part of the system of checks and balances.

A final difference between the post-Brown and the post-Roe cases has to do with the underlying moral positions of the opponents of the two cases. Racism is hardly defensible; anti-abortionism, while justifiably controversial, is at least a plausible moral position, and it is one which can plausibly be thought to oblige its adherents to use every legitimate means to curtail abortion. Under all these circumstances, then, the Court's condemnatory response to legislative attempts to restrict abortion to the constitutional minimum seems to indicate a hypersensitivity to its own righteousness and an insensitivity to the nature of the opposition to Roe.

I dwell on this point at perhaps undue length because $I$ have been struck by the frequency with which arguments of the kind I have made in this essay meet with the response that similar arguments might have produced a different result in Brown. It seems to me precisely a drawback of the trend toward constitutionalizing social issues that it encourages applying the same reasoning and rhetoric to social issues of widely differing kinds, and particularly that it makes Brown the paradigm rights case. Brown dealt with the great moral crisis of mid-twentieth-century America. Solutions that are appropriate to such a crisis are not necessarily appropriate to less severe social problems. 
resistance to modernity has found renewed voice. ${ }^{130}$ How much more it has found remains to be seen. But the question the battle raises is what kind of society we are to be. Politics is ordinarily the way in which such conflicts are worked out. And political solutions to such conflicts have their advantages. First, they need not be justified in an analytically rigorous way, a kind of justification that, as the Court's struggles with the privacy doctrine indicate, is tolerably, perhaps intolerably, hard to come by. Indeed, a drawback of relying on courts to resolve these conflicts is that courts must rely on reason, and not just on reason, but on their own, cramped, lawyer's ideas about what reason is. Yet the usefulness of judicial reason in these areas is limited by the absence of the kind of empirical evidence that would make rational analysis possible, by the fact that many family law statutes work (if they work) nonrationally, and by the fact that these statutes implicate basic value choices to which the Constitution either does not speak or only mumbles. There is, in short, no reason to believe the Court is likely to produce a wiser solution to the problems of modernity than the political branches, and there is some reason to believe that its solutions are likely to be distorted by its own composition and, as Weber would remind us, by its own modernizing function.

A further advantage of a political, as opposed to a judicial, solution to the conflict over what sort of society we are to be is that it can give people some sense of control over their environments and their lives. That sense of control is particularly important, I would suppose, for people who for economic and social reasons have relatively little of it anyway and who confront an elite equipped not just with considerable political power, but with prepotent cultural power.

In evaluating the problems I have been considering in this essay, we need to look dispassionately and realistically at what a more flexible state-interest standard, or even the deconstitutionalization of family law, would actually mean. In much of the country and as to many privacy issues, either change would make little immediate difference, given the present liberalizing tendency: Many of the reforms which have been or might be required constitutionally have been widely adopted legislatively. Many of the states which have not reformed their statutes rarely enforce them. Generally speaking, there has never been a time in American society when the range of choices about family and sexual life has been as great as it is now. This is not only because of the relative weakness of both formal and informal social regulation, but because of the relative wealth both of individuals (which gives people access to more ways of living and increases their capacity to resist social control) and of society (which increases the kinds of activities which can be made available and decreases society's need to regulate many forms of behavior). Nor would the values expressed by the privacy doctrine go unrepresented even if family law were deconstitutionalized: First, rights

130. It has actually found several, often conflicting, voices. Much of the "counterculture" of the 1960 's, for instance, expressed a different (and, in class terms, differently situated) anti-modernism. 
thinking is far too deeply ingrained in the American mind; second, elite positions (which are, as we should recall, generally liberal ones) on family law issues are, by hypothesis, those of people well situated economically, socially, and politically to defend them. ${ }^{131}$ Indeed, despite a popular conservative President and apparent conservative electoral power, the conservative "social program" remains conspicuously unenacted. ${ }^{132}$ Further, although I have argued against too blithely assuming that social change is unidirectional, we may be undergoing a change in attitudes toward family law matters that will eventually be quite complete, so that what is now the elite view will become nearly universal. Let me suggest two kinds of evidence that the modernists will win as they have won before. The first is the stunning rate of change in family and sexual life, a rate that suggests that the forces impelling it-for example, increasing urbanization, education, and economic well-being-run deep. ${ }^{133}$ The second is the fact that the young are almost thoughout society much friendlier to the relevant aspects of modernity than the old. Consider, for instance, the fascinating study of young elite evangelicals by James Davison Hunter, which indicates that evangelicals generally, and younger evangelicals particularly, are moving toward modernist views about many social issues involving the family. ${ }^{134}$ If the salt of tradition have lost his savour, wherewith shall it be salted? In short, if the change will occur anyway, the problem is to accomplish it as painlessly as possible, which will not be done by making the change a national and class issue.

\section{ConClusion}

I embarked on this essay to learn something about the desirability of constitutionalizing social issues like family law and vice. To narrow the essay's focus, I selected one aspect of fourteenth amendment privacy law, namely, state-interest analysis. I found a good deal to criticize. Doctrinally, the Court's troubles began in its efforts to formulate a standard for evaluating state interests. Once that standard was established, the Court found that it could not always be used. Even when it used the established standard, the Court did not define the standard's terms. The Court developed several

131. For a description of a situation in which Congress and federal administrative agencies were more rights-oriented than the courts, see R. Katzmann, Institutional Disability: The Saga of Transportation Policy for the Disabled (1986).

132. See Schneider, supra note 103, at 1870-75.

133. See generally P. ClecaK, supra note 120.

134. J. Hunter, Evangelicalism: The Coming Generation (1987). He writes that

large sectors of the Evangelical population (particularly within the younger cohort) no longer accept the legitimacy of traditional (bourgeois) role assignments, and one is left with a normative pattern of family life that is very untraditional indeed. . . [T]he Evangelical family specialists (including many ministers) advocate and defend a model of the family that is said to be traditional but in fact has no real historical precedent in Christendom or anywhere else) [sic] in the name of a constituency that has largely abandoned il in favor of an androgynous/quasi-androgynous model.

Id. at 114 (emphasis in original). See also Skerry, supra note 118, at 77, who cites evidence of declining class differences in the relationships of husbands and wives. 
substitutes for defining those terms, but the substitutes were problematic in principle and, partly because of the Court's difficulties with empirical evidence, unsatisfactory in practice. This series of failings is troubling not just because it represents serious doctrinal deficiencies, but because it suggests and exacerbates the severity of some of the larger problems with constitutionalizing social issues. These larger problems are further suggested and exacerbated by the Court's tendency to see statutes in isolation from their legal context. Finally, the Court's insensitivity to the social, cultural, and political contexts of privacy disputes has further diminished its capacity to analyze them acutely or resolve them wisely.

This essay is meant to be exploratory, not dispositive; suggestive, not conclusive. But it points to some promising lines of inquiry into the problem of constitutionalizing social issues. For instance, the Court's doctrinal difficulties with defining privacy suggest that a social issue may be inapt for constitutionalization if the novel constitutional principle to be employed is not reasonably clear, reasonably coherent, and reasonably limited. The Court's doctrinal difficulties in formulating and applying a standard for evaluating state interests suggest that a social issue may be inapt for constitutionalization when the state's interests are numerous, various, and weighty and when they operate in complicated ways that are not well understood. The Court's limited view of the state interests that may conflict with privacy rights and its incapacity to take into account the political and social context in which its decisions operate suggest that a social issue may be inapt for constitutionalization where the issue is difficult and embedded in larger political, social, and cultural conflicts. A common theme of these suggestions may be that complex social issues are inapt for constitutionalization, at least where the constitutional text gives courts little guidance and where courts cannot devote detailed and sustained attention to the problem.

The criticisms I have made seem to me to indicate some reasons to look skeptically at the constitutionalization of social issues like family law and vice. Nevertheless, I wish to restate what may have been obscured during my examination of standard state-interest analysis and my cautious and conditional defense of the facial constitutional legitimacy of the socialization argument. First, I have not argued that the Court's problems with its stateinterest formulae are necessarily fatal to the enterprise of fourteenth amendment privacy. I have not done so partly because any such conclusion would depend on a full study of the fundamental-rights side of the ledger (and, for that matter, on a fuller treatment than I have attempted here of the state-interest side). Furthermore, the Court's problems with its formulae should be evaluated in terms of the inconveniences and inadequacies of any judicial formula and in terms of the undoubted services-of discipline, economy, and predictability - such formulae render. Second, I have not endorsed the "socialization" argument as a matter of legislative policy. I have not done so because I have not yet worked out what I think about it generally 
and because I am opposed to its implementation in many particulars. It bears emphasizing that my argument in this essay leaves me free to oppose that strategy politically: I have simply argued that the socialization strategy may sometimes be regarded as a legitimate state interest in fourteenth amendment cases. Third, I have not contended that a statute defended on socialization grounds ought necessarily to prevail against a privacy attack. I have not done so because, accepting arguendo fourteenth amendment privacy rights, I do not regard every statutory implementation of the socialization strategy, however marginal or intrusive, as inevitably strong enough to withstand any privacy attack, however pressing.

On the other hand, I acknowledge that my criticisms and doubts could corrode fourteenth amendment privacy doctrine as now understood. This is true for several reasons. First, the doctrinal failings I have described are serious and significantly curtail the Court's capacity to evaluate state interests accurately and to weigh them intelligently against privacy rights. Second, those failings indicate that the Court has not successfully rationalized the privacy doctrine's constitutional status or its social function. Third, the socialization argument could turn out to have a considerable scope and thus put considerable constraints on privacy rights. Fourth, the seriousness of the social and cultural conflicts I have described and the desirability of social and political compromise both suggest at least the need for more sensitivity, tact, and judgment in deploying the privacy doctrine.

How alarmed one should be at any corrosion of the privacy doctrine depends in part on how certain one is of its constitutional legitimacy. I myself am inclined to believe that the privacy doctrine was unfounded as a matter of constitutional interpretation and unwise as a matter of judicial policy. This is not the place to explore those doubts. ${ }^{195}$ But let me close by suggesting that insights into them may be derived from some of the analytic approaches developed in this paper. For example, a more complex understanding of the privacy right may be reached by recalling what we learned about the propensity in state-interest analysis to isolate factors for analysis. The Court's formulae, we saw, break thought into fragments, isolating means from ends, means from means, and ends from ends. The Court's techniques have the same effect on the personal-rights side of the equation. There we see a right to privacy usually justified by its role in promoting autonomy. Autonomy is an individual and a social good. But it too needs to be seen in its context. Let us briefly look at how this might be begun.

Two considerations suggest how complex privacy analysis would be if autonomy were taken in context. First, autonomy is not the only individual and social good, and thus unlimited autonomy is unlikely to be individually desired or socially desirable-or, of course, even possible. What is needed, then, is to make available an optimal, not a maximal, level of autonomy. Calculating the optimal level of autonomy is complicated, since in doing so

135. I have tried to explore some of the reasons for this inclination in Schneider, supra note 103 
one needs to consider everything that contributes to autonomy, including the expansive range of choices and freedoms modernity brings. Because the Court hears only the cases that come to it and hears them one at a time, it is ill-situated to have a good sense of either the optimal or the actual level of autonomy. It can only weigh what it takes to be the unilateral good of autonomy against whatever particular interests the state proposes.

Second, even if autonomy were a unilateral good, it still might not be best served by sustaining every privacy-based autonomy claim. Once again, such claims need to be seen in context. The regulations that are challenged in privacy cases are intended to help construct and sustain social institutions for the conduct of sexual and family life. Such regulations limit autonomy in the interests of those institutions. But such "restrictive" institutions can themselves heighten the socially available level of autonomy, and thus the privacy doctrine ought not too lightly be used to erode such institutions. First, as Martin Krygier writes, "There are many social situations where our decisions are strategically interdependent [with the decisions of other people]

[I]n such situations, norms will be generated which provide 'some anchorage; some preeminently conspicuous indication as to what action is likely to be taken by (most of) the others ....'"'136 The institutions created by such norms, then, enhance the level of available autonomy by improving the ability of people to predict and thus to rely on and cope with the behavior of other people.

These "restrictive" institutions can augment autonomy in a second way. Without such institutions every individual would have to decide personally every detail about how to organize his life. "Today," Peter Berger writes, "it is not so much that individuals become convinced of their capacity and right to choose new ways of life, but rather that tradition is weakened to the point where they must choose between alternatives whether they wish it or not .... $[\mathrm{O}]$ ne of the most archaic functions of society is to take away from individuals the burden of choice." 137 The point here is not that the burden of choice is in any particular instance intolerable; it is that at some point the combined burdens become intolerable, or at least become so numerous as to distract one from other significant choices and thus to detract from one's autonomy in other areas. ${ }^{138}$

Restrictive institutions may enhance autonomy in a third way. Social critics of many stripes see American culture and personality as molded by the demands of a modern consumerist, capitalist society. On the view of such critics, individual people, even small groups of people, are too weakly situated to shape their own lives in the face of such demands. Government is perhaps the only social institution strong enough to support the restrictive institutions

136. Krygier, Law as Tradition, 5 LAw \& PHIL. 237, 258-59 (1986) (emphasis in original).

137. P. Berger, Toward a Critique of Modernity, in Facinc UP ro Modernity 77 (1977) (emphasis in original). See generally P. Berger, The Heretical Imperative 1 -29 (1979).

138. For example, see A. Cherlin, Marriage, Divorce, Remarriage 87-89 (1981) for an examination of the problems caused for parents in second marriages by the absence of institutional guidelines for such households. 
which can be one assertion of the individual against the pressures of those economic forces. For the large number of people who want to live in a society given stability, familiarity, and seriousness by restrictive institutions and the values they represent, government's support of those institutions is a preeminent means to effectuate their choice about how to live. And employing the government for that purpose can help give them the sense of efficacy, of control over their environment, which is a prerequisite to any exercise of autonomy. ${ }^{139}$

These brief comments, then, are intended as hints that the criticisms I have made of the Court's state-interest analysis may point us to similar kinds of criticisms of the Court's fundamental-rights analysis generally. Some of those criticisms will have to do with the kind of difficulties I discussed in the first part of this essay-difficulties in articulating the privacy right and in applying its accompanying doctrinal equipment. Others of those criticisms will have to do with the kind of difficulties I discussed in the second part of this essay-difficulties with the social consequences of constitutionalization. The reader may well feel that ultimately, both sets of difficulties (though particularly the latter set) are more properly political than constitutional. But of course that is exactly the point: In deciding privacy cases, courts have been dealing primarily not with questions about how social disputes are generally to be structured, but rather with how a particular social dispute should be resolved. That is what makes substantive due process special. But society's needs and wants are much more fluid, complex, and opaque than constitutional thought - which must develop rules of wide and determinate applicability that properly and permanently balance basic values-can easily accommodate or than judges-who have many other calls on their abilities and energies-can readily comprehend. The ideas about social compromise and about how quickly and thoroughly modernity should be socially assimilated that I probed in part IV seem to me examples of the kind of considerations that ought to be part of a resolution of some privacy issues but that constitutional law is hard pressed to doctrinally absorb. They thus seem to me to exemplify some of the reasons we should be cautious and modest in constitutionalizing vice issues in particular and social issues in general.

\footnotetext{
139. This is, of course, a problematic kind of autonomy, because it is secured at the cost of the comparable autonomy of people who would prefer a different kind of society. However, as I wrote earlier, this problem is, to some extent, unresolvable: It is a paradox of autonomy that autonomy requires control over one's social environment, but that to achieve that control someone else's autonomy must be diminished.
} 